\title{
Information and Communication Technologies
}

\section{of households and individuals, geographical}

\section{proximity and regional competitiveness:}

\section{distribution, clusters and spatial patterns}

\section{of technological capacity in Europe}

Tecnologías de la Información y Comunicación de los hogares

e individuos, proximidad geográfica y competitividad regional:

distribución, clústeres y patrones espaciales

de la capacidad tecnológica en Europa

\section{Reyes González-Relaño}

rgrelano@us.es

Ángel Luis Lucendo-Monedero

angeluis@us.es

\section{Francisca Ruiz-Rodríguez}

fruiz@us.es

Department of Physical Geography and Regional Geographical Analysis

University of Sevilla (Spain) 


\begin{abstract}
Information and Communication Technology (ICT) has been consolidated as a fundamental pillar of the new model of competitiveness and sustainable development of territories. However, there has still not been sufficient in-depth study of the role that geographical proximity plays in the digital inequalities that affect regional competitiveness. In this context, this paper aims to identify and characterise the clusters and patterns that define the spatial behaviour of ICT access and usage variables at household and individual level in the Technology Readiness (TR) pillar of the Regional Competitiveness Index (RCI). A database of 280 NUTS2 has been created in order to perform: i) an exploratory statistical analysis to show the regional behaviour of the ICT variables; and ii) a spatial autocorrelation analysis to detect the presence of spatial dependence. The results at regional level in Europe demonstrate that: i) the greatest inequalities occur in the ICT usage variables and not in those of access; ii) the indicators of TR create a spatial pattern with a gradient from the regions of the extreme north-west to south-western and eastern Europe; and iii) there is evidently an opportunity to incorporate other regional variables of ICT usage for future editions of the $\mathrm{RCl}$.
\end{abstract}

Key words: Regional Competitiveness Index (RCI); Technological Readiness (TR); spatial analysis, European regions (NUTS2).

\title{
Resumen
}

Las Tecnologías de la Información y Comunicación (TIC) se han consolidado como pilar fundamental para el nuevo modelo de competitividad y desarrollo sostenible del territorio. Sin embargo, aún no se ha profundizado suficientemente sobre el papel que la proximidad geográfica ejerce sobre las desigualdades digitales que inciden en la competitividad regional. En este contexto, el objetivo de este trabajo es identificar y caracterizar los clústeres y patrones que definen el comportamiento espacial de las variables de acceso y uso de las TIC de los hogares-individuos en la dimensión Technological Readiness (TR) del Regional Competitiveness Index (RCI) europeo. Se ha creado una base de datos de 280 NUTS2 para realizar: i) un análisis estadístico exploratorio para mostrar el comportamiento regional de las variables TIC; y ii) un análisis de autocorrelación espacial para detectar la presencia de dependencia espacial. Los resultados a nivel regional en Europa muestran que: i) las mayores desigualdades se dan en las variables de usos de TIC y no en las de acceso; ii) los indicadores del TR dibujan un patrón espacial con un gradiente desde las regiones del extremo noroccidental hacia el suroccidental y 
oriental; y iii) se evidencia la oportunidad de incorporar otras variables regionales sobre usos de $\mathrm{TIC}$ para futuras ediciones del $\mathrm{RCI}$.

Palabras clave: Índice de Competitividad Regional (RCI); Preparación Tecnológica (TR); análisis espacial; regiones europeas (NUTS2).

\section{Introduction}

There is no doubt today that the Information Society and technological services such as the Internet and other Information and Communication Technologies (ICTs) have been consolidated as a fundamental pillar of the new model of competitiveness and sustainable development of territories (Bisk \& Bołtuć, 2017; Ziemba, 2019; Sáiz Peña, 2019). Hence, Agenda 2030 for Sustainable Development explicitly recognises the potential of ICTs to facilitate interconnection and accelerate global human development (Perez Castro, Mohamed-Maslouhi \& Montero-Alonso, 2021).

To date, the scientific literature has concentrated on studying and demonstrating that ICTs play an important role in growth and economic development at national level (Inklaar, O'Mahony \& Timmer, 2005; Koutroumpis, 2009; Rohman \& Bohlin, 2014; Jordá-Borrell \& López-Otero, 2020; Banerjee, Rappoport, \& Alleman, 2020). In this respect, there is abundant literature on the concepts and indices that reflect the different dimensions of development and competitiveness (Möbius \& Althammer, 2020; United Nations Development Programme, 2017), although some authors still assert that the notion of competitiveness is ambiguous and lacks a common definition (Möbius \& Althammer, 2020). On the other hand, most of these indices are treated at national level, such as the ICT Development Index (IDI) published by the United Nations International Telecommunication Union; the E-Government Development Index (EGDI) of the United Nations Department of Economic and Social Affairs and the Network Readiness Index (NRI) published by the World Economic Forum (Perez-Castro et al., 2021), among others.

Nevertheless, many researchers defend the inclusion of the regional dimension in the analysis of competitiveness in Europe (Malecki, 2007; Keating, 2017) despite the fact that the state of research at this level of analysis is still embryonic (Möbius \& Althammer, 2020). In general, regions are considered to be an intermediate level between nations and municipalities (Keating, 2017), they have their own regulations and institutions and their own historical and geographical environment (Sbeppard, 2003) and they compete for production factors such as a highly skilled 
workforce, risk capital, foreign direct investments and the establishment of large companies (Camagni, 2002; Malecki, 2004).

One of the indices widely accepted by the scientific community for the analysis of the competitiveness of European regions is the Regional Competitiveness Index (RCI), published by the European Union, which follows the methodology of the Global Competitiveness Index of the World Economic Forum (GCI-WEF) (Annoni \& Dijkstra 2013; Annoni \& Dijkstra, 2019). The index measures a region's capacity to provide an attractive and sustainable environment for firms and residents to live and work in. It uses more than 70 indicators to measure different aspects and dimensions of regional competitiveness by means of sub-indices. Among these, the $\mathrm{RCl}$ Innovation sub-index includes pillar 9, Technological Readiness (TR), which is composed of 9 indicators: 3 related to ICT and households and individuals; 3 related to the availability, absorption and transfer of technology; and another 3 on ICT usage by enterprises. Of these 9, only 3 have a regional data source (those concerning ICT usage and access by households and individuals), while the other 6 are based on national level data which, in order to be comparable, have been regionalised (Annoni \& Dijkstra, 2010; Annoni \& Dijkstra, 2019).

Thus, and related to the difficulty of obtaining data at regional level, the main indices created by diverse institutions to measure the technological capacity of enterprises and/or individuals have mainly been applied at country level. One example of this is measuring digitalisation, which is done by using the ICT Development Index (IDI) of the International Telecommunication Union (2018), the Networked Readiness Index (Portulans Institute, 2019) or the Digital Economy and Society Index (DESI) (European Commission, 2020), among others. However, and in relation to these, recent studies (Ruiz-Rodríguez, Lucendo-Monedero \& González-Relaño, 2018) have shown that these national indices are not appropriate for measuring regional differences in digital readiness, given that they also entail a series of restrictions. It is worth mentioning, for example, a simplification of the complex interrelationships between ICT variables; the inadequate selection of the variables related to ICT technologies; or the random weight assigned to each indicator or variable when calculating the indices (OECD,2008; Bruno, Esposito, Genovese \& Gwebu, 2011; Corrocher \& Ordanini, 2002). In this respect, European regional data (at NUTS2 level) may be viewed via Digital Economy and Digital Society Statistics at Regional Level (Eurostat, 2020), although the conclusions drawn do not reflect European regional diversity.

Furthermore, and although the $\mathrm{RCl}$ has been used in a number of studies (Snieška \& Bruneckienè, 2009; Aiginger \& Firgo 2017; D’Urso, De Giovanni, Massari \& Sica, 2019; Aria, 
Gaeta \& Marani, 2019), there has still not been sufficient in-depth study of the role that geographical proximity plays in the digital inequalities that affect regional competitiveness. As Haefner and Sternberg (2020) indicate, there is very little scientific and empirically valid evidence as to what the spatial implications of digitalisation are. In fact, very little is yet known about the spatial behaviour of ICT access and usage by European citizens (households and individuals) on the basis of the geographical proximity of territories (Ruiz-Rodríguez, GonzálezRelaño \& Lucendo-Monedero, 2020).

In this context, an analysis of the spatial disparities of the ICT variables of households and individuals included in the $\mathrm{RCl}$ may reveal the existence of spatial patterns and structures, which would enable the formulation of prior hypotheses for econometric modelling and, where appropriate, spatial regression research on this aspect. In this respect, some studies have been conducted on ICT usage at national level in Europe by means of spatial analysis techniques (spatial autocorrelation) (Grubesic \& Murray, 2005; Van Dijk, 2006; Ruiz-Rodriguez et al., 2020). These demonstrated that geographical proximity is relevant in explaining the diffusion of ICT usage and virtual space. As Pick and Nishida (2015) note, a country with a high level of ICT usage could be influential on neighbouring countries leading them to raise their levels of digital usage. However, for the regional context, and specifically in the case of Europe, there are very few references to an in-depth analysis of the effects of geographical proximity as a factor to take into account in analyses of ICT usage by households and individuals (Billon, Lera-Lopez, \& Marco, 2017).

Therefore, this paper is motivated by the need to better understand the spatial behaviour of the variables of ICT access and usage by households and individuals in relation to European regional competitiveness. The spatial analysis of the ICT variables included in the Technological Readiness pillar of the European Regional Competitiveness Index should facilitate the understanding of digital inequalities from a regional perspective. Taking the arguments set out above as a starting point, the following questions are posed: what is the spatial behaviour of the variables of ICT access and usage by households and individuals included in the Technological Readiness pillar? And, are there any other ICT access and usage variables at household and individual levels in Europe that could be included in the Technology Readiness pillar to shed light on regional differences? Hence, this paper aims to identify and characterise the clusters and patterns that define the spatial behaviour of ICT access and usage variables by households and individuals in the Technology Readiness pillar of the RCl. To answer the aforementioned research questions, we will: i) explore the regional differences in Europe for all ICT access and usage variables by 
households and individuals through descriptive and spatial dependency statistical analysis; and ii) analyse and compare the spatial distribution of the Technology Readiness pillar with the Technology Readiness-Households and Individuals sub-pillar and its component indicators by identifying clusters of regions and spatial patterns.

In the following sections the paper addresses the state of play with regard to the digital inequalities and spatial analysis of ICT infrastructure and usage by households and individuals and, in particular, technological readiness for regional competitiveness. Below, the methodology used to ascertain territorial distribution and the existence of clusters of regions and spatial patterns in Europe is explained. Subsequently, the results obtained are set out and discussed. A final section presents the conclusions based on results that would be useful for future editions of the $\mathrm{RCl}$ and ensuing research, for the scientific literature and for drawing up regional policies that could help to reduce pre-existing spatial inequalities, taking into account the spatiality of the phenomenon.

\section{Theoretical framework}

International organisations frequently affirm that greater ICT adoption and usage helps nations, societies, businesses and people increase progress and welfare (Bahrini \& Qaffas, 2019; Avgerou, 2010; Ramírez-Correa, Grandón \& Rondán-Cataluña, 2020), and even more so when the transformation of services is accelerating, driven by current technologies that are rapidly increasing in velocity, capacity, connectivity, functionality and ease of use (Parasuraman \& Colbi, 2015). The rhythm of technological change has accelerated with the dissemination of high-speed Internet access, e-commerce, social networks and cloud computing, among other uses (Biagi \& Falk, 2017). Thus, now well into the twenty-first century, there is no doubt that the relationship between innovation and digital revolution is more than consolidated, both for enterprises and for individuals. A clear example of this is what occurs in countries where the impact of technological innovation is particularly noteworthy (Finland, Switzerland, Sweden and the Netherlands, for example) and where there are high levels of ICT usage both within the business fabric (RamírezCorrea et al., 2020; Hunady, Pisar \& Durcekova, 2020; Añón Higón, 2012) and by households and individuals (Lucendo-Monedero, Ruiz-Rodríguez \& González-Relaño, 2019).

For its part, the concept of technological readiness contemplates the propensity of people to adopt and use new technologies to achieve beneficial objectives, both in their private lives and at work (Parasuraman, 2000; Parasuraman \& Colbi, 2015). This perspective is relevant because it analyses the behaviour of individuals in relation to technology and reveals that if the population of 
a country or region is not open to new ICTs, the future development of its territory may be affected (Ramírez-Correa et al., 2020). People's access to and use of ICTs plays an important role in a competitive environment (Peña-Vinces, Cepeda-Carrión \& Chin, 2012) since the use of ICTs in the business sector would not be possible if there were not personnel qualified in ICT. Hence, the innovative capacity of individuals and the technological readiness of households and individuals directly affects such specific actions as the intention to purchase technology (Jeong, Yoo \& Heo, 2009), the adoption of electronic devices, the purchase of mobiles (Saprikis, Markos, Zarmpou \& Vlachopoulou., 2018) and diverse uses of ICTs (Schmidthuber, Maresch \& Ginner, 2020). Furthermore, other studies argue that people's experience with ICTs has a positive impact on technological readiness (Blut \& Wang, 2020), and especially on innovation, so that regional competitiveness partly depends on the capacity of individuals to take advantage of the opportunities offered by ICT (Castellacci, Consoli \& Santoalha, 2020). This therefore underlines the usefulness of studies that address e-readiness, understood as the ability of a country to be prepared, willing to adopt, use and benefit from e-innovations (Aboelmaged, 2014).

Therefore, the focus on the concept of technological readiness is in accordance with the agility with which an economy adopts existing technologies to improve the productivity of its industries, with special emphasis on the capacity to fully take advantage of ICTs in daily activities and production processes to increase efficiency and enable innovation (World Economic Forum, 2018). Currently, the European Union intends to contribute to the technological readiness of territories by implementing the European Digital Agenda (European Commission, 2010; Vicente \& López, 2011) and adopting the Digital Single Market Strategy (European Commission, 2015) as one of its 10 main political priorities. This strategy has 16 initiatives that cover three major areas: promoting better online access to goods and services across Europe; designing an optimal environment for digital networks and services to develop; and ensuring that the European economy and industry take full advantage of the digital economy as a potential driver for growth (Ruiz-Rodriguez et al., 2020). At present, however, each European country implements and manages its digitalisation strategy differently and at a different pace, which does not really help to reduce spatial inequalities in digital matters (Uljas, 2019; Cruz-Jesus, Oliveira \& Bacao, 2012). Thus, recent studies have revealed the existence of disparities between northern and southern Europe in the ICT usage of households and individuals and, to a lesser extent, in the availability of ICT infrastructures (Billon, Ezcurra \& Lera-López, 2009; Tranos \& Gillespie, 2009). Countries in the north have concentrated on widespread availability and use of e-government and other 
public services, which has led to massive broadband deployment (Falch \& Henten, 2018). Countries in south-eastern Europe, however, are still in the phase of developing infrastructures through the implementation of policies to develop the broadband network (Ragnedda \& Kreitem, 2018). Regional differences, therefore, exist today due to different advanced uses and the socioeconomic benefits that individuals obtain from ICTs (Hargittai, 2010; Ragnedda, 2017).

Accordingly, some authors such as Haefner and Sternberg (2020) affirm that despite efforts from the public sphere to counterbalance digital inequalities there is still no evidence of a reduction in the socio-economic disparities between different territories in Europe (lammarino, RodríguezPose \& Storper, 2019). Hence it is necessary to promote measures that foster digitalisation and take access to ICTs to all territories while simultaneously encouraging their use. However, this digital decentralisation driven by ICT access and usage has been questioned by other researchers (Camagni \& Capello, 2005; Cairncross, 2018) because there is still little scientific and empirically valid evidence with regard to the spatial implications of digitalisation in regions' economic, political and social spheres (Castellacci et al., 2020; Haefner \& Sternberg, 2020). The divide in ICT access and usage (Briglauer, Dürr \& Gugler, 2019; Lobo, Alam \& Whitacre, 2020) still hinders competitiveness and only the regions whose firms and individuals have sufficient digital skills to use ICTs efficiently can successfully meet the challenges of digitalisation, seize their opportunities and reduce the gap to other more advanced regions (Haefner \& Sternberg, 2020). A regional and spatial analysis of digital skills continues to be relevant as long as these are not introduced or activated uniformly in all territories (Corrocher \& Ordanini, 2002), with different consequences for their technological readiness, innovation and competitiveness (Richardson \& Bissell, 2019; Castellacci et al., 2020).

Nonetheless, as Otioma, Madureira \& Martinez (2019) indicate, most of the literature on measuring and explaining ICT usage does not include spatial aspects despite the fact that geographical distance and the degree of spatial agglomeration determine the probability of being connected (Tranos, 2012). With this argument, studies have been undertaken on ICT usage by applying spatial analysis techniques (spatial autocorrelation) at national and regional level in Europe, the United States, Japan and China, among others (Grubesic \& Murray, 2005; Van Dijk, 2006; Uljas, 2019). All these coincide in indicating that space and geographical proximity help explain the territorial diffusion of digitalisation. Consequently, as Pick and Nishida (2015) point out, a territory with a high level of ICT usage could influence neighbouring territories, inducing them to raise their levels of digital usage. It is thus necessary to know whether the differences and similarities in the digitalisation of regions are related to geographical 
proximity (Schlichter \& Danylchenko, 2014; Novo-Corti \& Barreiro-Gen, 2015) and, specifically, whether these differences can be discerned with an analysis of the spatial behaviour of the variables of ICT access and usage by households and individuals used in the Technological Readiness pillar of the European $\mathrm{RCl}$.

\section{Methodology}

\subsection{Data}

The data necessary to undertake this study come from two European Union sources:

i) Eurostat's "ICT Use by Households and Individuals" survey database. From this source 8 ICT variables of households and individuals in European regions have been selected (Table 1). These variables have been chosen based on the criteria of type of access, frequency and use of ICTs. The data are from 2018 and their unit of measurement is the percentage of households and individuals in each region.

Table 1. Variables used from "ICT usage by households and individuals" of the Eurostat Regional Information Statistics (at NUTS2 level)

\begin{tabular}{|l|l|c|}
\hline \multicolumn{1}{|c|}{ VARIABLES } & MEASUREMENT & $\begin{array}{c}\text { REFERENCE } \\
\text { YEAR }\end{array}$ \\
\hline Use internet banking & \% of individuals & 2018 \\
\hline Submitting completed forms (last 12 months) & \% of individuals & 2018 \\
\hline Interaction with public authorities (last 12 months) & \% of individuals & 2018 \\
\hline Online purchases: travel and holiday accommodation & $\%$ of individuals & 2018 \\
\hline Individuals who accessed the internet away from home or work & \% of individuals & 2018 \\
\hline Individuals who accessed the internet daily & $\%$ of individuals & 2018 \\
\hline Selling goods or services & $\%$ of individuals & 2018 \\
\hline Participating in social networks & $\%$ of individuals & 2018 \\
\hline
\end{tabular}

Source: elaborated by the authors

ii) The European Union's Regional Competitiveness Index ${ }^{1}(\mathrm{RCI})$. Four variables have been selected from the Technology Readiness pillar: one corresponds to the Technology Readiness pillar (which is composed of two sub-pillars, see Annex 1); and three others form the Technology Readiness-Households (TR-HI) sub-pillar: Households with broadband access (indicator), Individuals purchasing via the Internet (indicator), and Household Internet access

1 The $\mathrm{RCl}$ is made up of three sub-indices that are organized into 11 dimensions or pillars, which in turn total 74 different indicators (https://ec.europa.eu/regional_policy/en/information/maps/regional_competitiveness/). 
(indicator) (Table 2). In addition, a fifth variable corresponding to the Technology ReadinessHouseholds and Individuals (TR-HI) sub-pillar has been constructed by calculating the average of its three indicators.

The variables selected from the $\mathrm{RCl}$ databases are in different units of measurement: while the TR data (as for all pillars) are standardised in z-scores, the three indicators that compose the TR-HI sub-pillar are data in percentages of individuals or households. Therefore, for the comparative statistical and geospatial analyses, these indicators have been standardised using the same method (z-scores). As with Eurostat data, the time reference is 2018.

Table 2. Variables used from $\mathrm{RCI}$ or compiled from $\mathrm{RCl}$ data (at NUTS2 level).

\begin{tabular}{|c|c|c|}
\hline INDICATORS/NARIABLES & MEASUREMENT/SOURCE & $\begin{array}{l}\text { REFERENCE } \\
\text { YEAR }\end{array}$ \\
\hline $\begin{array}{c}\text { Technological Readiness TR } \\
\text { (pillar) }\end{array}$ & $\begin{array}{l}\text { \% of households and enterprises (z score) / } \\
\qquad \mathrm{RCl}\end{array}$ & 2018 \\
\hline $\begin{array}{c}\text { Technological Readiness-Hogares } \\
\text { (sub-pillar TR-HI) }\end{array}$ & $\begin{array}{c}\text { \% of individuals and households (z scores) / } \\
\text { Own elaboration based on RCl dates. }\end{array}$ & 2018 \\
\hline $\begin{array}{l}\text { Households with access to } \\
\text { broadband (indicator) }\end{array}$ & $\begin{array}{l}\text { \% of total households (z scores) / } \\
\text { Own elaboration based on } \mathrm{RCl} \text { dates. }\end{array}$ & 2018 \\
\hline $\begin{array}{l}\text { Individuals buying over internet } \\
\text { (indicator) }\end{array}$ & $\begin{array}{c}\text { \% of individuals (z scores) / } \\
\text { Own elaboration based on } \mathrm{RCl} \text { dates. }\end{array}$ & 2018 \\
\hline $\begin{array}{l}\text { Household access to internet } \\
\text { (indicator) }\end{array}$ & $\begin{array}{l}\text { \% of total households (z scores) / } \\
\text { Own elaboration based on } \mathrm{RCl} \text { dates. }\end{array}$ & 2018 \\
\hline
\end{tabular}

Source: own elaboration based on the Regional Competitiveness Index (RCI)

Both sources, Eurostat and $\mathrm{RCl}$, provide data for European regions at NUTS2 (Nomenclature of Units for Territorial Statistics) level based on the $2016^{2}$ classification. However, data for Germany, Greece, Poland, the United Kingdom and Hungary are only available at NUTS1 level. Therefore, for these countries, data for NUTS1 regions have been extrapolated to NUTS2 level (as the RCI methodology does for those variables that are only available at NUTS1 level), so that statistical analyses can be performed at that regional level. The total number of regions studied is 280 NUTS2 regions from the 28 EU Member States ${ }^{3}$.

2 See https://ec.europa.eu/eurostat/web/nuts/background

$3 \mathrm{RCl} 2019$ was computed including the United Kingdom as a member of the EU because the reference period of all the indicators included in the Index is prior to the country's official departure date from the Union (31 March 2019). Consequently, all the EU averages include 28 Member States (Annoni \& Kozovska, 2019) 


\subsection{Exploratory statistical data analysis}

An exploratory statistical analysis was performed on all data on access, frequency and type of ICTs use by households and individuals at NUT2 level in Europe (Table 1 and 2). The intention was to explore the characteristics of the distribution of these data at European level and identify the most important statistics: values of central tendency and dispersion values via standard deviation and amplitude; detect atypical cases and ascertain existing relationships between analysed variables. The idea was, on the one hand, to examine the data to obtain a basic understanding of the variables of ICT access and usage in European regions and provide an overview of the situation and determine what differences exist in ICT implementation and usage; and discern the main uses of ICTs by individuals in the EU. Moreover, on the other hand, the information thrown up by the descriptive statistical analysis helps orient the subsequent spatial analyses.

\subsection{Exploratory Spatial Data Analysis (ESDA)}

Exploratory spatial data analysis (ESDA) is used to identify and understand the spatial behaviour of variables on ICT infrastructure and use by households and individuals at regional level. This method is applied when, as indicated by Chasco (2009) and Buzai \& Baxendale (2009), no prior information is available on the nature of these relationships and, in addition, an approximation to the study of the spatial information structure of these relationships is desired. ESDA brings together a set of techniques that: i) describe and visualise spatial distributions; ii) identify atypical locations or spatial outliers; iii) discover spatial association schemes, clusters or hot spots; and iv) suggest spatial structures or other forms of spatial heterogeneity (Anselin, 1999). ESDA would thus correspond to spatial descriptive statistical methods (Buzai \& Baxendale, 2009).

Using the ArcGis Pro software from ESRI and the vector coverage from Eurostat's spatial database GISCO NUTS2 2016, which contains the European NUTS2 shapefile, the data of Tables 1 and 2 were georeferenced in order to obtain the Global Moran's I Index of all the variables and indicators. In order to understand the spatial behaviour of the TR pillar and their indicators (Table 2), the values of the Z-scores or standard deviations are represented cartographically. The resulting maps show the differences and inequalities in the spatial distribution of these variables and discover whether these values are geographically concentrated or, on the contrary, whether they are randomly distributed or dispersed. However, Serrano and Vayá (2002) state that the information obtained with previous spatial distribution maps, although useful, is subjective and 
highly dependent, among other things, on the number of intervals selected to represent the data. Therefore, if it is possible to have a general idea of the spatial patterns when creating a cartographic representation, then just by using spatial autocorrelation analysis it is possible to quantify these patterns, locate them and identify whether they are concentrated, dispersed and/or atypical schemes of spatial association. The concept of spatial autocorrelation refers to the concentration or dispersion of the values of a variable in space and is based on the existence of a similitude between what happens in a region and its neighbours, in accordance with Tobler's first law of geography Tobler (2004).

Consequently, this GIS a spatial autocorrelation analysis is carried out to study the degree of spatial concentration of all the variables (Table 1 and 2) on infrastructure and ICT use of the households and individuals. First, an analysis of spatial dependence is carried out by calculating Moran's global l-index. This index measures spatial dependence by jointly considering the locations and the values of the entities. If the value is positive (regions have similar values to their neighbours), this signifies that the values tend to group; if it is negative (differing values among neighbouring regions), this indicates a dispersion of values; and if the value is 0 this means there is no autocorrelation (the values of neighbouring regions have randomly-produced values).

Secondly, to identify and locate the spatial clusters or groups of regions that have similar values for the indicators related to the TR pillar (Table 2) the local spatial autocorrelation indices are calculated for each entity or region. When the Anselin local Moran's I index (LISA or cluster analysis and outlier value analysis) has a high z-score and p-value (positive or negative), this signifies that statistically the values of the variables studied are spatially concentrated, producing a spatial cluster of a high-high (HH) or low-low (LL) type. The LISA index also reveals the presence of dispersed or outlier values of the high-low $(\mathrm{HL})$ or low-high $(\mathrm{LH})$ type. A second index of local spatial dependence was also used: the Getis-Ord $\mathrm{Gi}^{*}$ or optimised analysis of hot spots. This index makes it possible to measure the degree of grouping of regions and raises the possibility of a null hypothesis (which establishes that there is no spatial clustering for the values of entities). If the p-value returned by the calculation is small and statistically significant, the null hypothesis may be rejected; and if the z-score is positive, there is a cluster of high values (hot spot); whereas if it is negative there is a cluster of low values (cold spot). Furthermore, entities receive a value $( \pm 0,1,2$ and 3 ) according to the statistical confidence level (which corresponds to reliability levels of $0 \%, 90 \%, 95 \%$ and $99 \%$, respectively). 
In order to calculate the spatial autocorrelation indices, a $k$ number of the nearest neighbours is considered to be vicinity between regions. This conceptualisation of relations of vicinity is based on contiguity and establishes that two spatial entities are neighbours if they share a common a common edge of length different to zero. From the options offered by the ArcGis Pro software, "K-nearest neighbours" was chosen, with K being equal to 8 (the 8 regions contiguous to each region). This type of vicinity between regions was chosen because, according to ESRI (2020), this method is appropriate and effective when: i) the values of the entities are skewed (they are not distributed normally); ii) the distribution of data varies in the area of study in such a way that some entities are far from the other entities. This is what occurs with the European NUTS2 regions and therefore, in this case, measuring vicinity taking into account the quantity of neighbours is more important than the scale of analysis and/or the distance between entities; and iii) each entity has a minimum number of neighbours, which is a necessary condition for spatial autocorrelation analysis. Finally, $K$ is equal to 8 (the 8 contiguous regions to each region) as it is the average number of neighbouring regions that each European NUTS2 has calculated with ArcGis Pro for the set of polygons analysed.

\section{Results and discussion}

\subsection{Exploratory and spatial dependency analysis of ICT access and usage variables in European regions}

From the exploratory statistical analysis of the variables of ICT access and usage (Table 1 and 2) it follows that ICT access and infrastructure provision in European regions is widespread throughout the territory and differences are due to the uses that citizen make of these technologies. Indeed, as shown in Table 3, almost 9 of every 10 European households have both internet access (87.6\% of the total), and broadband (85.3\% of households).

However, the level of ICT usage by households and individuals is lower in European regions with only $76.1 \%$ of European individuals who accessed the internet daily; and almost $70 \%$ did so away from home or work ("on the go", that is, using portable devices such as mobile and/or smart phones, laptops, tablets or handheld devices). The analysis of type of use shows that only slightly more than half of households and individuals in European regions engage in advanced uses. Thus, while an average almost $60 \%$ are participating in social networks on average, other variables such as selling goods or services (56.6\%), use internet banking (55.2\%) and interaction with public authorities (an average of $53.8 \%$ of the individuals in each region) have lower values. 
Table 3. Descriptive statistical analysis of the ICT variables (2018)

\begin{tabular}{|l|c|c|c|c|c|}
\hline \multicolumn{1}{|c|}{ VARIABLES } & AVERAGE & $\begin{array}{l}\text { STANDARD } \\
\text { DEVIATION }\end{array}$ & RANGE & MINIMUM & MAXIMUM \\
\hline Use internet banking & 55.2 & 21.2 & 91.0 & 3.0 & 94.0 \\
\hline Submitting completed forms & 35.2 & 18.7 & 80.0 & 2.0 & 82.0 \\
\hline Interaction with public authorities & 53.8 & 18.5 & 90.0 & 3.0 & 93.0 \\
\hline $\begin{array}{l}\text { Online purchases: travel and holiday } \\
\text { accommodation }\end{array}$ & 31.9 & 17.9 & 69.0 & 1.0 & 70.0 \\
\hline $\begin{array}{l}\text { Individuals who accessed the internet } \\
\text { away from home or work }\end{array}$ & 69.9 & 15.0 & 58.0 & 33.0 & 91.0 \\
\hline Individuals Buying Over Internet* & 26.4 & 12.5 & 66.0 & 3.0 & 69.0 \\
\hline Individuals who accessed the internet daily & 76.1 & 12.0 & 51.0 & 45.0 & 96.0 \\
\hline Selling goods or services & 56.6 & 11.2 & 57.0 & 34.0 & 91.0 \\
\hline Participating in social networks & 59.4 & 11.1 & 58.0 & 34.0 & 91.0 \\
\hline $\begin{array}{l}\text { Households with access to } \\
\text { broadband* }\end{array}$ & 85.3 & 8.1 & 43.0 & 56.0 & 99.0 \\
\hline Household access to internet* & 87.6 & 7.7 & 35.0 & 64.0 & 99.0 \\
\hline
\end{tabular}

* ICT Variables Included in the TR-HI

Source: elaborated by the authors

If we consider the data for standard deviation, the dispersion of the values of the ICTs analysed for households and individuals in European NUTS2 regions with regard to the aforementioned average values stands out significantly. This indicates the existence of substantial inequalities at regional level in this respect. Nevertheless, it should be noted, as mentioned above, that these differences exist in level of use and not level of access, since households with access to broadband and household access to internet are the two ICT variables where the percentages of households are most similar or homogeneous (with a standard deviation of only around $8 \%$ in both cases). On the other hand, the greatest differences between the values of European regions occur for the different variables related to ICT usage with standard deviation values of over $15 \%$ from the average of individuals per region. Use internet banking (with $21.2 \%$ ) is especially notable, followed by submitting completed forms and interaction with public authorities (around $18.5 \%$ ), online purchases of travel and holiday accommodation (with almost 18\%) and individuals who accessed the internet away from home or work (with $15 \%$ ).

The values of range or divide between regions with the lowest or highest values for the ICT usage variables are directly related to these dispersion values (in fact, there is a $96 \%$ correlation between these two statistics according to Pearson's correlation coefficient). As mentioned above, the range shows the digital divide in European regions, which is $90 \%$ of individuals or over for 
use internet banking and interaction with public authorities; $80 \%$ for submitting completed forms; and $66 \%$ or over for online purchases of travel and holiday accommodation and order goods or services, over the Internet, for private use. As was pointed out for the average and the standard deviation, the digital divide is less (but not less important: from $35 \%$ to $43 \%$ ) with respect to the ICT variables related to access and infrastructures (household access to internet and households with access to broadband, respectively).

On the other hand, the results obtained by calculating the Global Moran's I spatial autocorrelation index make it possible to confirm that there is a spatial concentration of European regions with similar values to those of their neighbors in all the variables of ICT access and usage by households (Table 4). There is less than 1\% probability that these clustered spatial patterns are due to a random process, which indicates the spatiality of the phenomenon (López Hernández \& Palacios Sánchez, 2000).

The TR pillar, which comprises ICT access and usage by households plus availability and use by enterprises, has the highest spatial concentration value (0.90). This signifies that there is a geographical concentration of high and low values of technological capacity at regional level in Europe. The TR-HI sub-pillar, for its part, has an average Global Moran's I value (0.78), a result of the spatial behaviour of its three component indicators.

Table 4 Moran's Global Index of European regions

\begin{tabular}{|l|c|c|c|}
\hline \multicolumn{1}{|c|}{ VARIABLES AND INDICATORS } & $\begin{array}{c}\text { MORAN'S } \\
\text { INDEX }\end{array}$ & Z - SCORE & P - VALUE \\
\hline Technological Readiness Pillar (TR)* & 0.90 & 25.75 & 0.00 \\
\hline Use internet banking & 0.87 & 31.76 & 0.00 \\
\hline Online purchases: travel and holiday accommodation & 0.83 & 30.08 & 0.00 \\
\hline Household access to internet* & 0.82 & 23.34 & 0.00 \\
\hline Individuals who accessed the internet daily & 0.82 & 30.00 & 0.00 \\
\hline Selling goods or services & 0.79 & 28.73 & 0.00 \\
\hline Households and Individuals Sub-Pillar (TR-HI)** & 0.78 & 28.73 & 0.00 \\
\hline Individuals who accessed the internet away from home or work & 0.77 & 27.89 & 0.00 \\
\hline Interaction with public authorities & 0.72 & 25.99 & 0.00 \\
\hline Submitting completed forms & 0.70 & 25.65 & 0.00 \\
\hline Individuals buying over internet* & 0.68 & 24.65 & 0.00 \\
\hline Households with access to broadband* & 0.64 & 18.20 & 0.00 \\
\hline Participating in social networks & 0.62 & 22.62 & 0.00 \\
\hline
\end{tabular}

* Included in the RCI

** Prepared by the authors

Source: elaborated by the authors 
The indicators individuals buying over internet and households with access to broadband have very low spatial concentration values (0.68 and 0.64, respectively), whereas household access to internet has a high value (0.82). The first two indicators, which have less geographical concentration, also show a smaller divide between the values of European regions (standard deviation of $12.5 \%$ and $8.1 \%$, Table 3), indicating that there is a greater convergence of regions in terms of broadband access to ICTs compared with the spatial behaviour of regions in the TR pillar. Meanwhile, although household access to internet is the ICT indicator that has the smallest gap between the values of European regions (standard deviation of 7.7\%, Table 3), the high spatial autocorrelation value indicates that it has a different spatial behaviour, as there is a great geographical concentration of regions with high values and low values.

On the other hand, as regards the variables of ICT access and usage by households and individuals not included in the $\mathrm{RCl}$, the use internet banking variable stands out due to its high spatial dependence (0.87) and because it has the greatest divide and dispersion of regional values of all the ICT variables analysed (a difference of $91 \%$ between the regions with the highest and lowest values; and a standard deviation of $21.2 \%$, Table 3 ). This shows that the use of internet banking by households and individuals in European regions is not generalised, which reflects the inequalities in ICT usage. According to the autocorrelation index value, this variable is followed by online purchases travel and holiday accommodation and who accessed the internet daily $(0.83$ and 0.82 , respectively). These two variables, although they have similar spatial behaviour, show significant statistical differences. Hence, while the use of ICTs for online purchases of travel and holiday accommodation has values that are very unequal between regions (standard deviation of $17.9 \%$ and a divide of $69 \%$ ), the access the internet daily variable is more homogeneous at regional level (standard deviation of only $12 \%$ and a range of $51 \%$ ). The variables who accessed the internet away from home or work, interaction with public authorities and submitting completed forms have an average level of spatial autocorrelation (with values between 0.77 and 0.70). On the contrary, individuals participating in social networks shows the least concentrated spatial behaviour of all the ICT variables studied (Global Moran's I of 0.62), associated, in turn, with very little divergence of regional values (standard deviation of $11.1 \%$ and a range of $58 \%)$.

It follows from this analysis that, from among all the variables included in the TR, access to broadband may no longer be sufficient to show digital inequalities or progress as this infrastructure is now widely established in European households. In fact, there has been widespread use of broadband and digital devices in the European Union since the onset of the 
second decade of the twenty-first century (Scheerder, van Deursen \& van Dijk, 2017), and hence most individuals and households have access to ICTs.

Despite the fact that this indicator has been used to explain the differences between having or not having ICT access since the 1990s (Yu, 2006; Contreras-Cabrera, 2012; Tsetsi \& Rains,2017), studies have recently focused on measuring digital inequalities via the ICT usage of individuals and the social and economic benefits that these produce (Van Deursen \& Van Dijk, 2019). At present, aspects related to the advanced use of ICTs (commercial purposes or interaction with the public administration) are becoming necessary and appropriate variables to include in indicators to measure the technological capacity of regions (Ruiz-Rodriguez et al., 2020). Moreover, up until now, other technologies allow provision of the same services as broadband to households, and so the limitations that a substantial part of regions have in terms of broadband to households does not prevent their citizens accessing Internet and buying online. Therefore, aspects related to the advanced use of ICTs (for personal activities, commercial purposes or interaction with the public administration) are becoming necessary and appropriate variables for inclusion in indices that measure the inequalities and geographical concentration of the technological capacity of regions.

\subsection{Spatial analysis of the TR pillar, the TR-HI sub-pillar and its component indicators}

In relation to the analysis of the spatial distribution of the values of the TR pillar, of the TR-HI subpillar and of its component indicators, in European regions is shown in the maps of Figure 1. With regard to the TR pillar, on the basis of the z-score intervals used in Figure 1a, the existence of two great concentrations of regions with similar TR values, which illustrate a clear digital divide or inequality at spatial level between the regions of northern and central Europe and the southernwestern-eastern regions of the periphery of the European Union, can be clearly seen. Indeed, all, or nearly all, the regions of Ireland, the United Kingdom, Netherlands, Germany, Austria, Denmark, Sweden, Finland, Estonia and France have TR values above the European average. On the contrary, southern and eastern Europe, which includes most Spanish regions and all the regions of Portugal, Italy, Poland, Hungary, the Czech Republic, Slovakia and, especially, the Greek, Romanian and Bulgarian regions, have TR values below the average. In the spatial distribution, for both high and low values, the national dimension is present and yet, for intermediate values ( 0.5 above and below the average) the national component is diluted in the regions of some western countries, as occurs in the case of France, Spain and Belgium. 
Meanwhile, the values of the sub-pillar related to ICT access and usage by households and individuals (TR-HI) in European regions show a more random geographical distribution (Figure 1b). Thus, the high values of ICT access and usage continue appearing in almost all the regions of the countries in northern Europe (United Kingdom, Netherlands, Denmark, Lithuania and Estonia); yet this also true for some regions of Eastern European countries. Likewise, there is a more random spatial distribution in the values below the average, except in regional capitals that have higher values than their surrounding regions. Hence, while there are few regions with values below the average in northern Europe (in Ireland and Sweden), most of such regions are to be found in the central European corridor (French and Czech regions) and also in the western (Spain and Portugal) and north-eastern (Poland) peripheries. The lowest values for ICT access and usage are spatially concentrated in the southern regions of Italy, Romania, Bulgaria and Greece.

The analysis of the spatial distribution of the 3 indicators that make up the TR-HI sub-pillar (Figures 1c, 1d and 1e) show the following spatial pattern: above-average values in all or almost all the regions of northern and central Europe (Ireland, United Kingdom, Netherlands, Denmark, Finland, Lithuania and Estonia); and a large part of the regions of France (except for the Households with access to broadband indicator, Figure 1c), and also the regions of Austria and the Czech Republic. Once again the regions with below-average values are those of the south and south-east of Europe, with a clear difference between: a) the regions of Hungary, Romania, Bulgaria, Greece, Croatia and Italy, which have the lowest values; and b) the regions of Slovakia, Poland, Spain and Portugal, with average negative values.

It is therefore evident that the spatial distribution of the regional values of the TR pillar of the RCI reveal the existence of imbalances in ICT access and usage and technology adoption and absorption at regional level in Europe (Corrocher \& Ordanini, 2002; Moroz, 2017). However, the results of the comparative analysis of the spatial behaviour of the TR pillar and the TR-HI subpillar show that the TR of regions is influenced by a national component, that is, all the regions of the same country have similar values. This may be due to the fact that the TR pillar comprises not only the TR-HI sub-pillar but also another sub-pillar (TR-E) which itself is made up of 6 indicators constructed with data at national level whose values have been extrapolated to the regions. This may explain why the TR pillar shows the aforementioned spatial homogeneity of a national character in the values of the regions. This form of constructing the TR pillar may limit the use of analyses whose conclusions reflect the regional reality. Specifically, it is possible to study the convergence of regions in ICT access and usage by households and individuals (based on regional data) but with regard to the adoption of new technologies and ICT by firms (based on 
national data) the results may be misleading. This, in turn, raises the need to have regional statistics for all the indicators included in the TR pillar of the $\mathrm{RCl}$, with the aim of improving understanding of the regional reality regarding ICT access and usage and technological capacity in general.

Figure 1. Spatial distribution of the Technological Readiness Pillar (TR) and the ICT access and usage by households and individuals sub-pillar (TR-HI) at regional level (in z-scores) of the $\mathrm{RCl}$

a) Technological Readiness Pillar

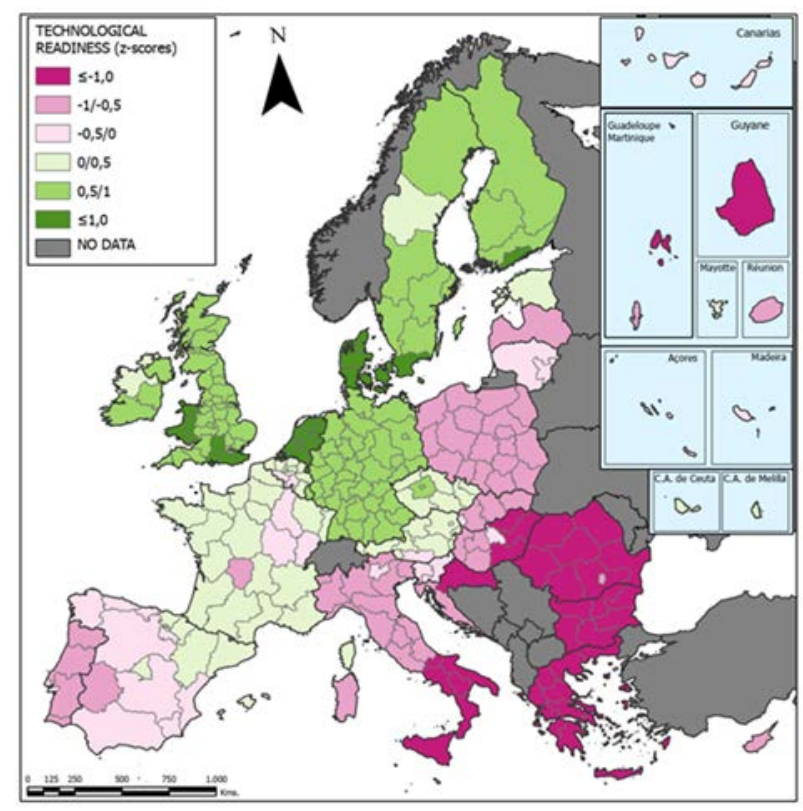

c) Households with access to broadband

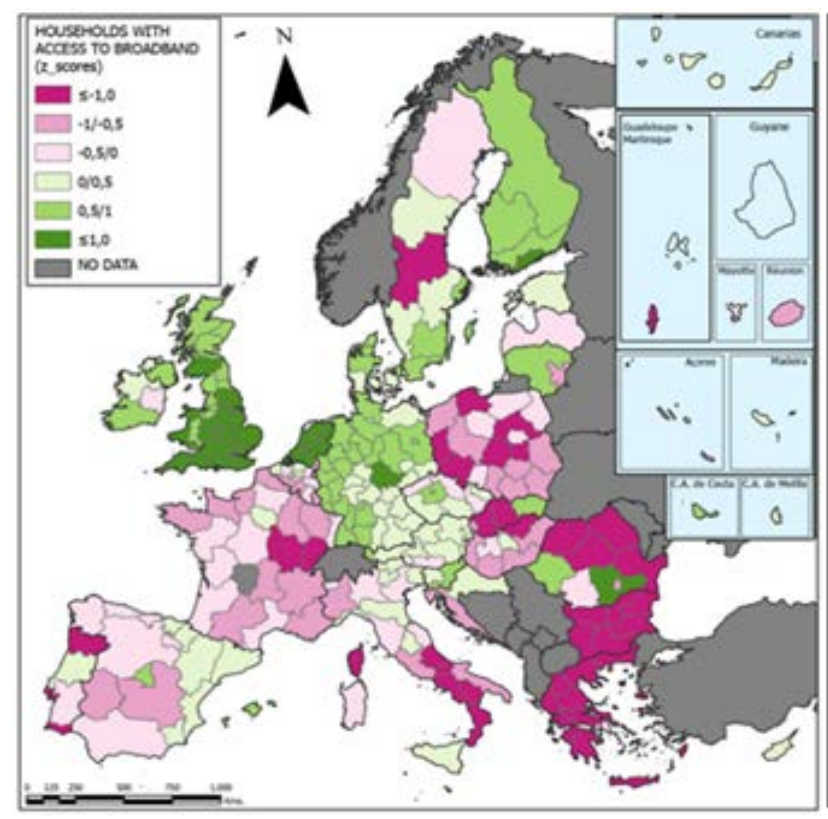

b) Households and Individuals Sub-pillar

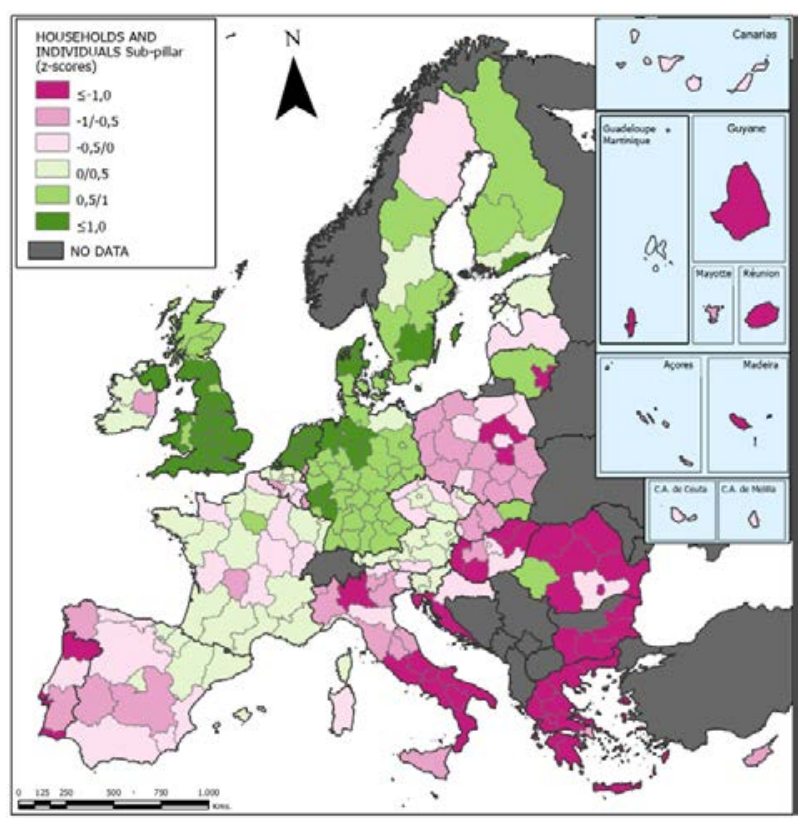

d) Households with access to internet

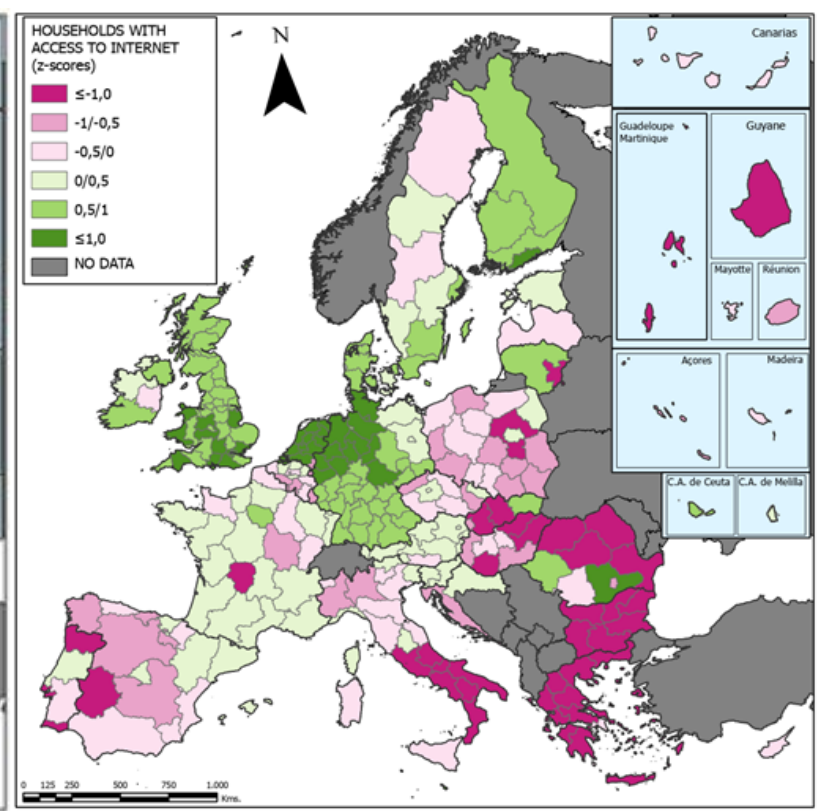


Figure 1. Continuation

e) Individuals buying over internet

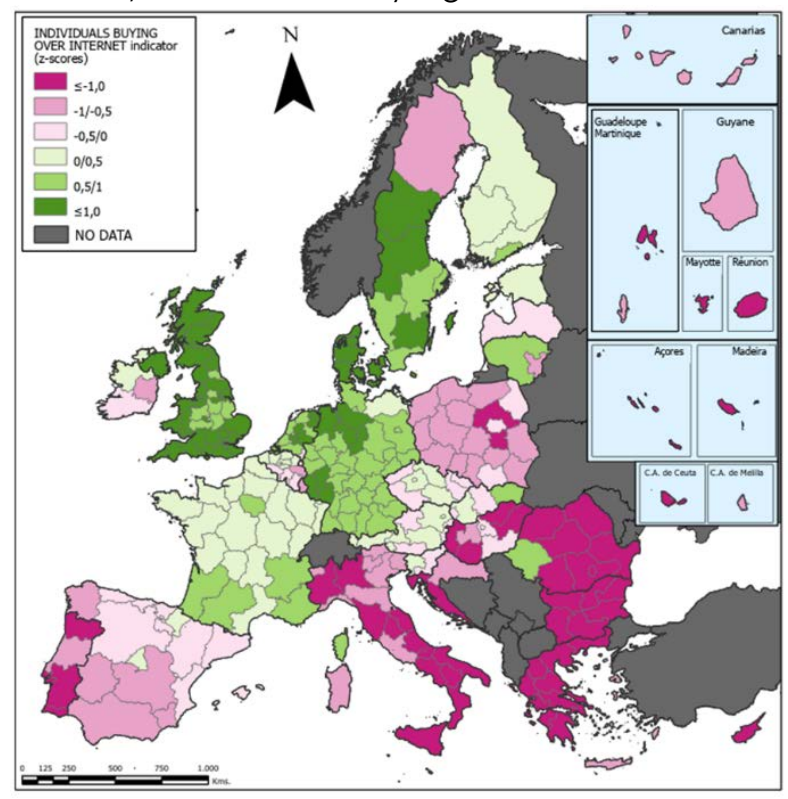

Source: elaborated by the authors

The spatial distribution maps of the variables of ICT access and usage reveal that this phenomenon does not occur in an isolated fashion, but rather there is a concentration of groups of regions with high and low values for both the TR pillar and the TR-HI sub-pillar and its indicators and, therefore, demonstrates a possible spatial autocorrelation.

Regarding local spatial autocorrelation, the analysis of the spatial dependence of the TR pillar, the TR-HI sub-pillar and its indicators by means of the Anselin local Moran's I index (LISA) and the Getis-Ord Gi* index makes it possible to discover where and what kind of spatial clusters of European regions comprise these variables; and to show the existence of spatial patterns with different levels of technological capacity and, specifically, levels of ICT access and usage of households and individuals at regional level in Europe.

The Anselin local Moran's I index (LISA) for the Technological Readiness variable (Figure 2a) shows the presence of three large spatial clusters that configure a spatial pattern in Europe with a north-east-south-east gradient in line with a higher to lower level of TR of regions:

1. A High-High $(\mathrm{HH})$ cluster of regions comprising those with high values of $T R$ in northern and central Europe (109 NUTS2, 39.2\% of the total). It includes all the regions of Sweden and Finland; those of Denmark, Netherlands, United Kingdom and Ireland; and most German regions. 
2. A Low-Low (LL) cluster of regions comprising those with lower levels of TR $(24.1 \%, 67$ NUTS2). This cluster is concentrated in eastern and south-eastern Europe, encompassing all the NUTS2 of Cyprus, Greece, Romania, Bulgaria and Lithuania; practically all the regions of Italy, eastern regions of Hungary; the central and eastern regions of Poland; and some regions of Croatia and Slovakia.

3. The cluster comprising the regions whose value on the LISA index has not been significant due to having values around the average. It is the second largest cluster with 100 NUTS2, $36 \%$ of the total. It is made up of the western European regions of Portugal, Spain, France and Belgium; the central European regions of northern Italy, Slovenia, Croatia, Austria and the Czech Republic; and the regions of eastern Germany, western Poland, Slovakia and Hungary; and to the north, Estonian and Latvian regions.

With regard to the results of the local Getis-Ord Gi* index for the TR pillar, a series of hot spots and cold spots can be identified that create a spatial distribution pattern of European regions with a north-west-south-east gradient with a higher to lower level of TR of regions (Figure 2b). The concentration of hot spots of European regions with high levels of TR (with a statistical certainty of over $95 \%$ ) occurs in a territorial corridor that runs from Ireland and the United Kingdom to Sweden and Finland, passing through the Netherlands, north-western Germany and Denmark. Meanwhile, the cold spots or clusters of European regions with lower levels of TR are made up of the regions of eastern Europe, especially those of Romania, Bulgaria, Greece, Italy and Cyprus, and some regions of Hungary, Slovakia, Croatia and the centre and east of Poland and Lithuania. Finally, and without statistical significance on the local Getis-Ord Gi* index, a cluster of regions can be detected that borders on the hot spots: regions of Portugal, Spain, France, Belgium, northern Italy, Austria, the Czech Republic, eastern regions of Germany, western regions of Poland, Estonia and Latvia.

The TR-HI sub-pillar creates a similar pattern to the TR variable (Figures $2 c$ and $2 d$ ) as it maintains the gradient of higher to lower value from the regions of the extreme north-west to south-western and eastern Europe, but with the difference that for this TR-HI sub-pillar, there are more outlier regions. Hence, on the one hand, the map of the Anselin local Moran's I index (Figure 2c) reflects a cluster of regions with High-High $(\mathrm{HH})$ values that contains 93 European regions (33.5\% of the total) of the United Kingdom, the Netherlands, Ireland except the capital region, the French region of Brittany, the regions to the north and centre of Germany, Denmark and the regions of southern Sweden. Another cluster of Low-Low (LL) regions is made up of the regions 
of Portugal, Extremadura in Spain, most of the regions of Italy (except the north) and Croatia, all the regions of Cyprus, Greece, Romania and Bulgaria, and the central regions of Poland and Hungary (66 NUTS2, 23.7\% of the total). As mentioned above, the spatial autocorrelation analysis of the TR-HI sub-pillar has thrown up a particularity, which is a greater number of regions with outlier values than in the TR pillar, as there are 2 NUTS2 with Low-High (L-H) indices in Ireland and Sweden; and 3 NUTS2 of the High-Low (H-L) type in Malta, Hungary and Romania. Additionally, as a result, the spatial cluster of regions with non-significant values or values close to the average for ICT access and usage by households and individuals is greater (41\% of the total) than in the TR pillar.

The results of calculating the local Getis-Ord Gi* index for the ICT access and usage by households and individuals variable (Figure 2d) show spatial clusters of both hot spots and cold spots, with a confidence level over $90 \%$. These clusters reflect a spatial distribution pattern similar to that defined by the LISA index, as the regions that form the hot spots are again located in north-western Europe, in the regions of Ireland, United Kingdom, Netherlands, central-southern Germany, Denmark and Sweden (73 NUTS2, $26.01 \%$ of the total); while the cold spots (97 NUTS2, 34.6\% of the total) are basically concentrated in the regions of south-eastern Europe (all the regions of Cyprus, Greece, Romania and Bulgaria; central-southern Italy and Croatia; and the regions of eastern Poland, Slovakia and Hungary) plus the western periphery (Portugal and the Spanish region of Extremadura). Furthermore, as well as the location of the clusters, the local Getis-Ord Gi*index makes it possible to see that the regions with a greater concentration of higher values of ICT access and usage by households and individuals (hot spot - $99 \%$ confidence) correspond to all the regions of the United Kingdom, Denmark and the Netherlands, as well as the regions of north-western and central Germany and southern Sweden. On the contrary, the regions where there is less ICT access and usage by households and individuals (cold spot-99\% confidence) are located in the south-eastern periphery of Europe, and include all the regions of Cyprus, Greece, Romania and Bulgaria; central-southern Italy; and the Algarve, in southern Portugal. 
Figure 2. Spatial clusters according to the Anselin local Moran's I index (LISA) and the Getis-Ord Gi* index for the Technological Readiness pillar (TR) and the Households and Individuals sub-pillar (TR-HI)

\section{TECHNOLOGICAL READINESS PILLAR}

a) Anselin local Moran's I index (LISA)

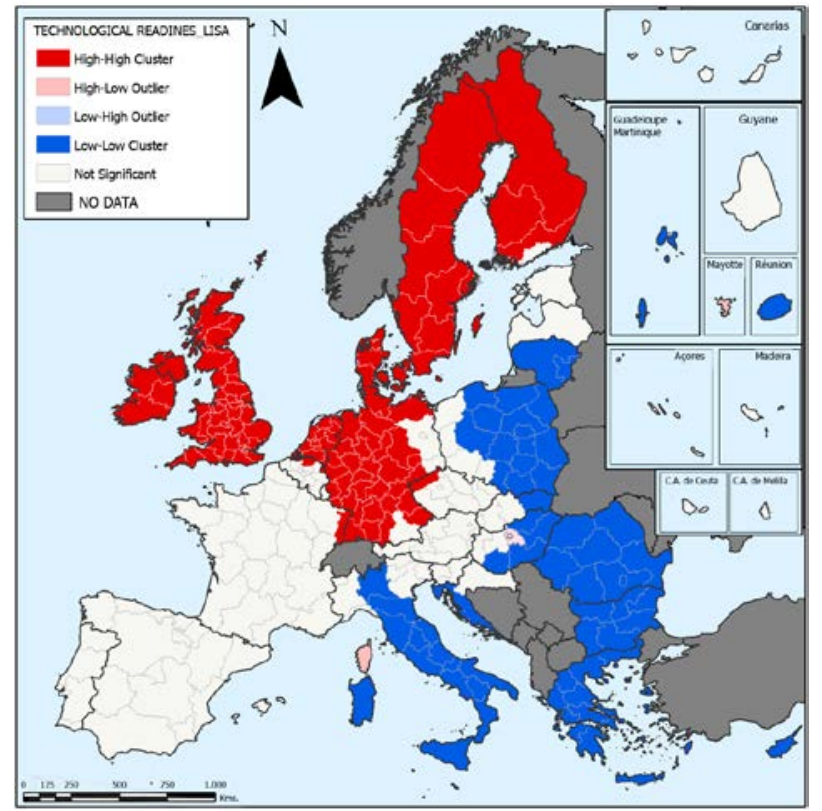

b) Getis-Ord Gi* index

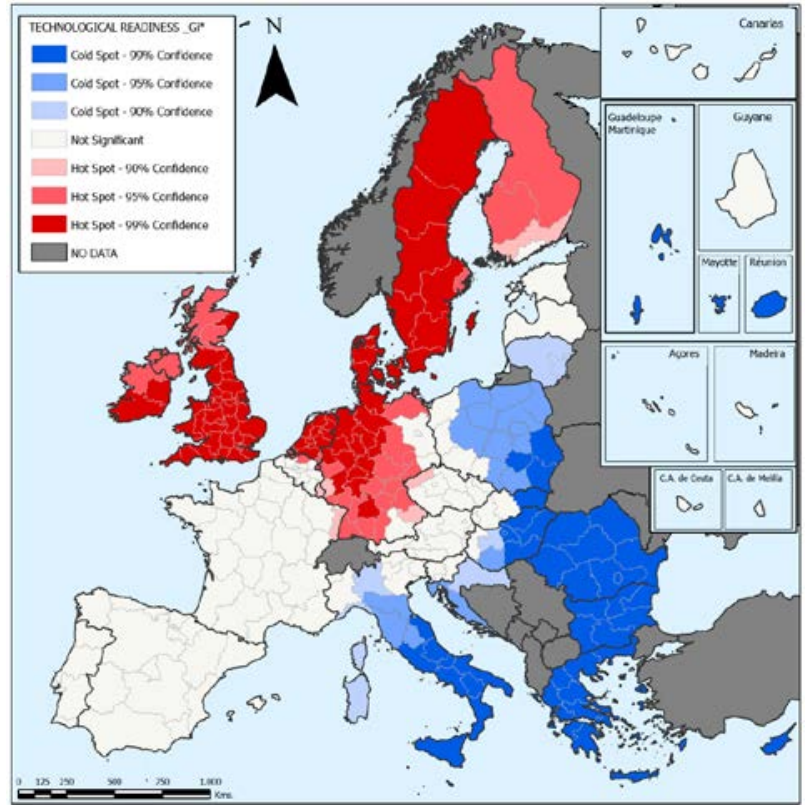

HOUSEHOLDS AND INDIVIDUALS SUB-PILLAR

c) Anselin local Moran's I index (LISA)

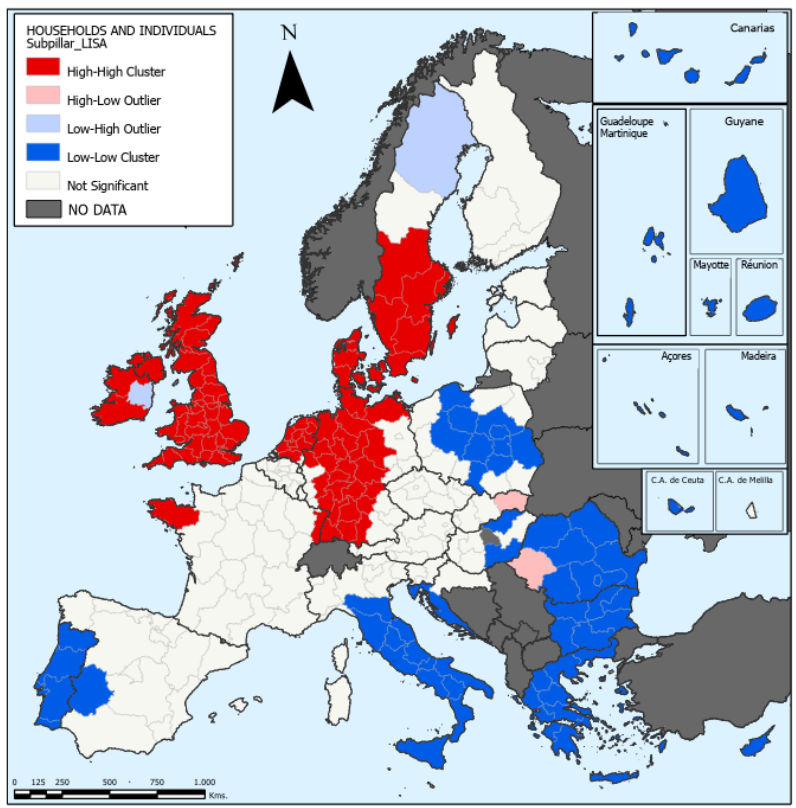

d) Getis-Ord Gi* index

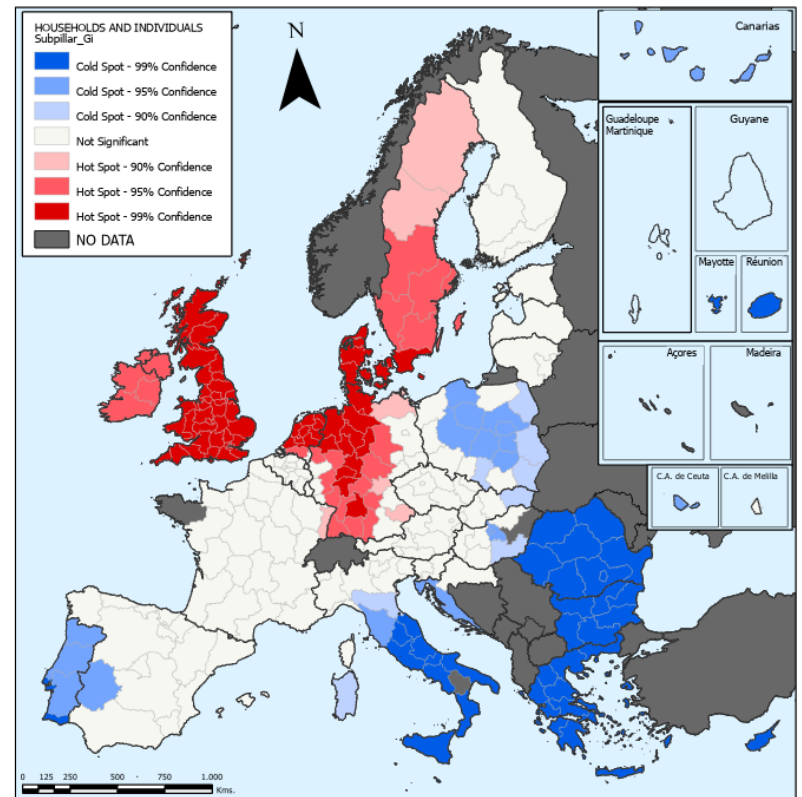

Source: elaborated by the authors

With regard to the spatial autocorrelation local analysis of the three indicators included in the TRHI sub-pillar (Share of individuals who used internet to order goods/services - Individuals-buying- 
internet; Share of households with internet access - Households-access-internet; and Share of households with access to broadband - Households-access-broadband), it shows that there is only a spatial distribution pattern or gradient in European regions similar to that already described for TR and TR-HI in the first two indicators (Figure 3a, 3b, 3c and 3d).

Indeed, for both the Individuals-buying-internet and the Households-access-internet indicators the Anselin local Moran's I index (LISA) and the Local Getis-Ord Gi* index show a distribution of the $\mathrm{HH} / \mathrm{LL}$ spatial clusters and hot-cold spots with a gradient of regions that starts from the highest values located in north-western Europe (United Kingdom, Ireland, Denmark, Netherlands and Germany, except its NUTS2 in the east) and runs to the lowest values of regions located in the east and the southern European periphery (Portugal, southern Spain, Italy, Croatia, Greece, Cyprus, Bulgaria, Romania and a few Hungarian, Slovak and Polish NUTS2). As for the size of the clusters, these are larger for the Individuals-buying-internet indicator than for Householdsaccess-internet, both for the $\mathrm{HH}$ and for the $\mathrm{LL}$ (made up of $33.5 \%$ and $24.5 \%$ of the total NUTS2 for the former; and $32 \%$ and $17.6 \%$ for the latter). The same occurs with the size of the hot spots and cold spots (35.7\% and $28.6 \%$, and $26.1 \%$ and $26.4 \%$, respectively).

Meanwhile, the spatial distribution clusters and patterns obtained for Households with access to broadband (Figure 3e) show a number of differences from the other two indicators, in relation to both their size and their location. First, with regard to the size of the $\mathrm{HH}$ and LL clusters, they are smaller, that is, there is a smaller number of European regions with values above or below the average (26.2\% and $19.8 \%$ of the total number of regions); or, otherwise, most European regions have similar values for Households-access-broadband (almost half, $49.6 \%$ of the total). This in turn means that there is a higher number of outlier regions, above all NUTS2 of the HL type (almost $4 \%$ ), in comparison with the other ICT variables analysed so far. Second, all of this is reflected in the location of these clusters and the appearance of spatial patterns for Households-access-broadband given that: i) the higher numbers of $\mathrm{HL}$ outlier regions are distributed throughout southern Europe, from Portugal, France and Italy to Slovenia, Hungary, Romania, Bulgaria and Cyprus; ii) the HH NUTS2 clusters remain in the northern European regions, especially in the United Kingdom and the Netherlands, but now there are less NUTS2 in Germany, Ireland and Denmark that have above-average values; and iii) the LL cluster is once again located in south-eastern Europe, especially in all the regions of Greece and Bulgaria and a few regions in Italy and Romania (those in the south of both countries) and in Poland (those that form a central corridor). However, on top of these, as an important anomaly, there is a fair number of regions in central-southern France with low percentages for the Households-access- 
broadband indicator, which have values close to the average in the LL clusters of TR, TR-HI, Individuals-buying-internet and Households-access-internet.

The same characteristics with regard to size and spatial distribution that we have indicated in the spatial clusters of Households with access to broadband obtained with the Anselin local Moran's I index (LISA) occur in the spatial clusters resulting from the local Getis-Ord Gi* index. Indeed, as can be seen in the map in Figure 3f, the hot spots are concentrated in the British Isles (Great Britain and Ireland), the Netherlands and a few regions in northern and central Germany, Denmark and southern Sweden (with the highest values or $99 \%$ confidence only clustering in the United Kingdom, the Netherlands and the German region of Weser-Ems). The cold spots continue to be concentrated mainly in south-eastern Europe (Cyprus, Greece, Bulgaria, Romania, Poland and southern Italy) and the odd western region (in Spain and Portugal). As occurred previously with the LL clusters, the regions of central France also have below-average values (cold spots).

In short, the analysis of spatial dependence has made it possible to verify the existence of statistically significant territorial clusters. Moreover, as regards the TR pillar, the clusters identified show that this indicator is conditioned by the use of data on economic and business characteristics at national level, although these data are weighted and extrapolated to each of the regions. As a result of this, the predominance of a spatial homogeneity of the behaviour of the TR of the regions within their national limits is observed.

On the contrary, the resulting spatial clusters for the TR-HI sub-pillar reveal a greater differentiation in the digital behaviour of regions. On the one hand, the clusters identified make it possible to know intra-national digital differences in greater detail. On the other hand, the clusters also indicate the existence of atypical digital behaviour in some regions with respect to their neighbours. Consequently, unlike for the spatial behaviour of the TR pillar, the TR-HI sub-pillar is created on the basis of regional data, which makes it possible to discern the real territorial inequalities in the digital development of Europe. Thus, the results lead to the interpretation that the spatial behaviour of TR would be due to the influence of the sub-pillar based on national data, that is, on the TR-E made up of indicators of ICT access and usage by European enterprises and their capacity of technology adaptation and absorption.

However, when spatially and individually analysing the only 3 indicators based on regional data, the existence of a regional convergence is perceived, underpinned by Households-accessbroadband due to the fact that a large part of European regions have very similar values, a result 
of the diffusion of broadband throughout European territory (Cava-Ferreruela \& Alabau-Munoz, 2006; Falch \& Henten, 2018). Hence, differences between regions will only be associated with the capacity to access internet (by any means) and the buying over internet indicator (the only indicator used to measure advanced ICT usage by households and individuals).

Finally, the analysis of the spatial dependence of TR and its components confirms the existence of a regional pattern of greater to lesser digital development from the north-west to the south and south-east of Europe. Consequently, it can be affirmed that, from an Economic Geography perspective, and using these variables, the different levels of ICT access and usage and capacity of technology adoption-absorption of European regions follow the spatial behaviour of the centreperiphery socio-economic development model (Jordá-Borrell, Ruiz-Rodríguez, \& GonzálezRelaño, 2015; Billon et al., 2017; Ruiz-Rodríguez et al., 2018).

However, the use of other regionalised ICT variables in the TR pillar could alter these results. The exploratory statistical analysis and the spatial autocorrelation analysis of the variables of ICT access and usage by households and individuals not included in the $\mathrm{RCl}$ show that other variables could be used to measure the digital inequalities of European regions. Indeed, the TR pillar does not include variables available at regional level on different uses of ICTs such as use internet banking, which turns out to be one of the ICT variables with greater spatial dependence and has the greatest regional inequalities. Likewise, the online purchases travel and holiday accommodation variable could be included in the TR pillar, since it has very disparate values and spatial behaviour in different regions, which could help to highlight digital inequalities between these regions. However, the spatial analysis of TR only contemplates the technological readiness of households and individuals based on ICT access, without taking into account what uses individuals make of ICT, whereas presently it is essential to use variables of type of use in order to understand the digital differences between European regions (Hargittai, 2010; Van Deursen \& Van Dijk, 2019). Moreover, when using the TR pillar, the substitution of weighted and extrapolated national data to measure ICT access and usage by enterprises may show a skewed reality, since digital development has different properties and dimensions at different levels, organised in a system of hierarchical relationships. In this respect, a geographical understanding of the prevailing processes of ICT implementation and usage, which determine small-scale spatial patterns, cannot necessarily be inferred from those that prevail at large scale and vice versa (Rivera \& Galicia, 2016). 
Figure 3. Spatial clusters according to the Anselin local Moran's I index (LISA) and the Getis-Ord $\mathrm{Gi}^{*}$ index for the three indicators included in the ICT access and usage by households and individuals sub-pillar (TR-HI)

INDIVIDUALS BUYING OVER INTERNET

a) Anselin local Moran's I index (LISA)

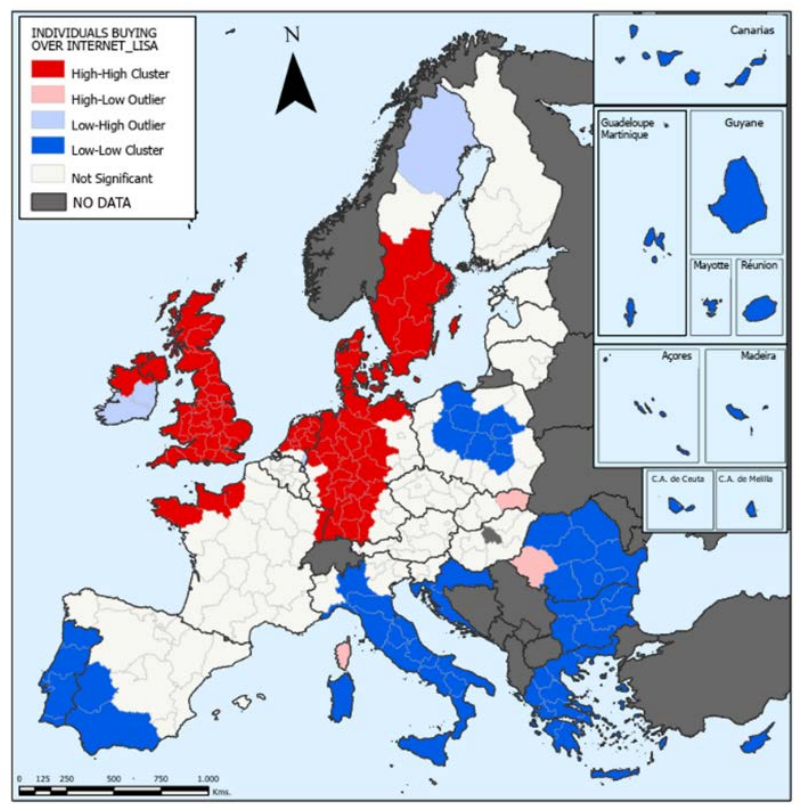

b) Getis-Ord Gi* index

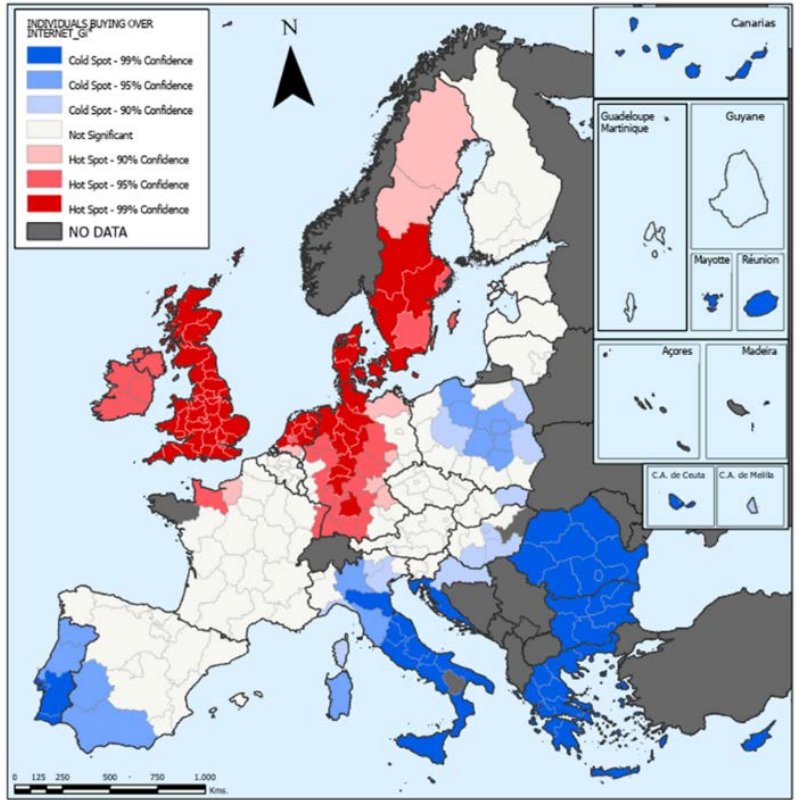

HOUSEHOLDS WITH ACCESS TO INTERNET

c) Anselin local Moran's I index (LISA)

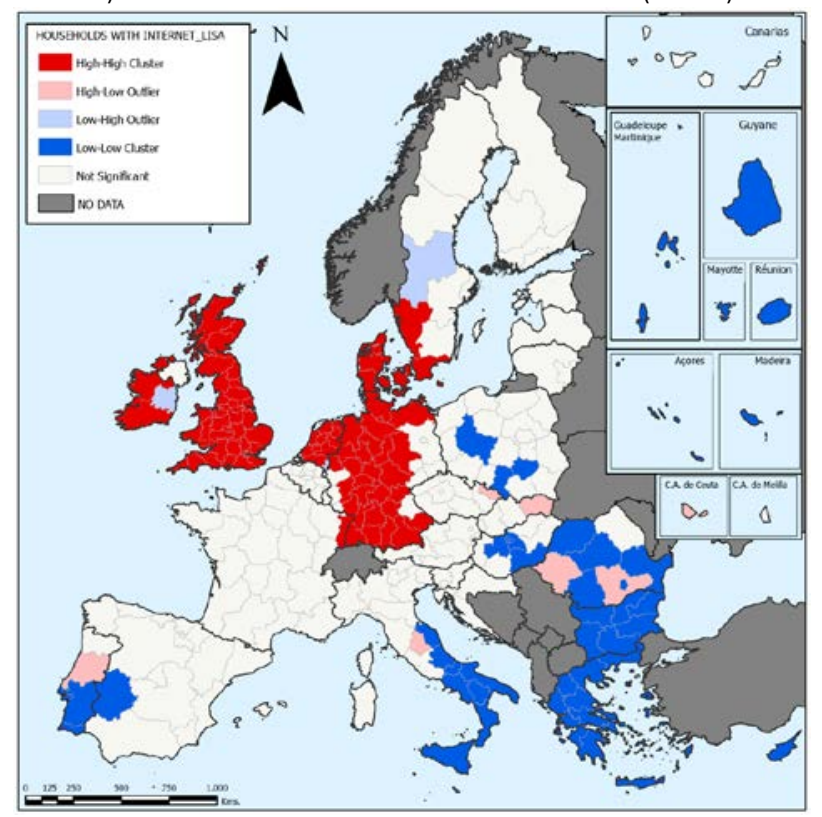

d) Getis-Ord Gi* index

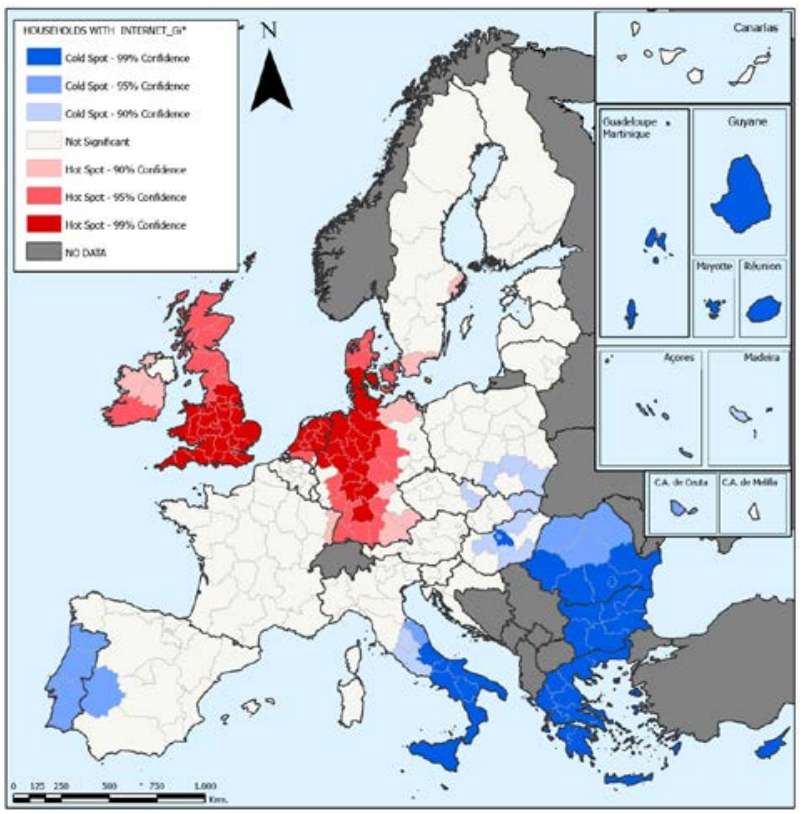




\section{HOUSEHOLDS WITH ACCESS TO BROADBAND}

e) Anselin local Moran's I index (LISA)

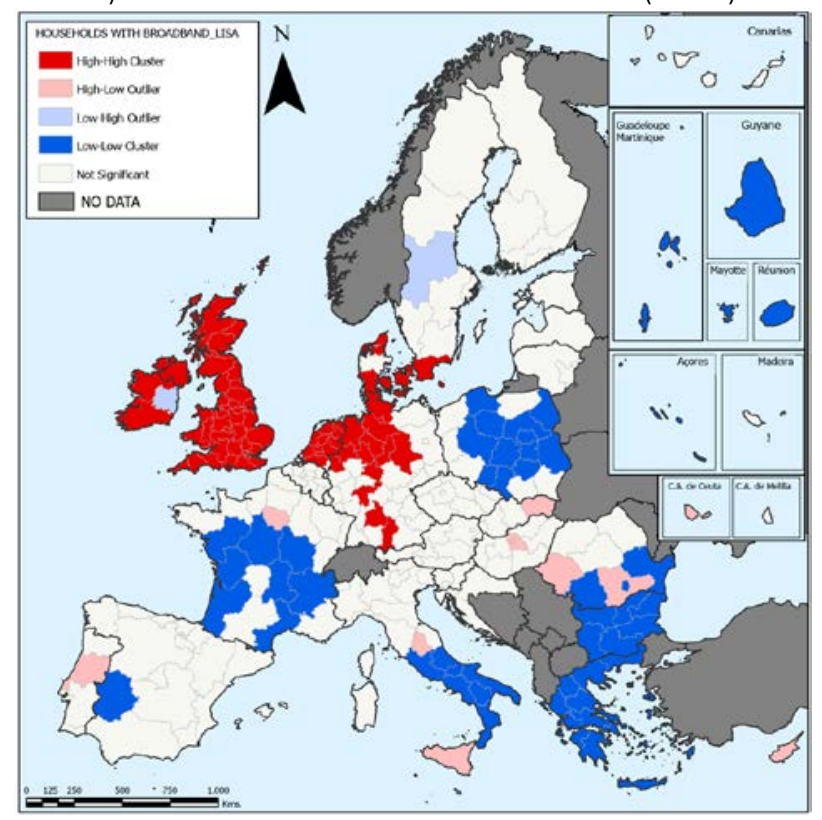

f) Getis-Ord Gi* index

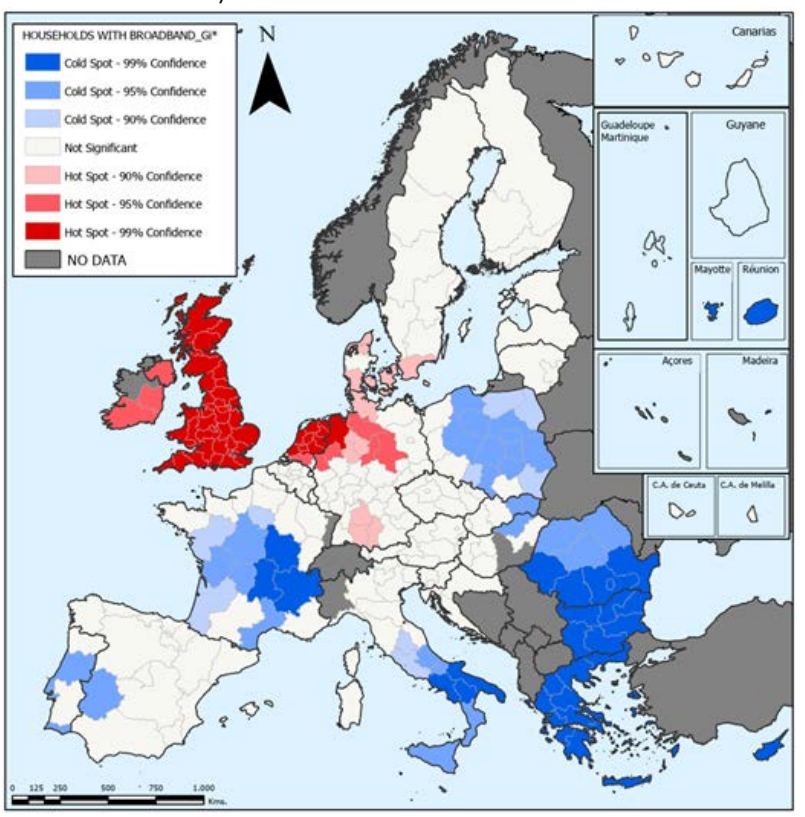

Source: elaborated by the authors

Furthermore, in line with the objective of the $\mathrm{RCl}$ to show the divergence or convergence of European regions (Annoni \& Dijkstra, 2019), the application of the spatial autocorrelation analysis helps to identify spatial clusters of dependence of neighbouring regions with lower levels of digital development. In this way, the results could help to identify how dependence between neighbouring regions would help the dissemination of ICTs from central regions to aid the regional development of the European periphery, from the point of view of convergence and integration linked to the digital economy (Sánchez-Moral, 2015).

\section{Conclusions}

The results of this research have shown that the use of the spatial autocorrelation technique is appropriate for studying digital inequalities at territorial level in Europe. The aim of the $\mathrm{RCl}$ is to detect the competitiveness of European regions, and in the specific case of the TR pillar, to show the different capacities of ICT access and usage and technology adoption-absorption. By means of the use of spatial autocorrelation analysis, spatial patterns and clusters with different levels of ICT access and usage of European regions have been identified.

The regional behaviour of the variables on ICT access and usage by households and individuals in Europe analysed indicates that, whereas ICT infrastructures for internet access and broadband are widely established and there are hardly inequalities between regions (these are the variables 
with less dispersion of values), different ICT uses do indeed show great digital disparities between individuals in European regions (differences of up to $91 \%$ between regions in the use of internet banking, interaction with public authorities and submitting completed forms). These facts have been demonstrated through global spatial analysis using the Moran's I index, given that the variables of ICT usage by individuals have shown greater levels of spatial dependence or concentration than those of infrastructure.

Furthermore, by means of the local spatial autocorrelation analysis of the TR pillar variables, spatial clusters and patterns of European regions with different levels of ICT access and usage have been identified. Thus, for the Technological Readiness pillar a clear spatial pattern is detected in Europe with a gradient from greater to lesser level of digital development from the European regions in the north-west to those in the south and south-east. However, less regional inequality is observed among levels of ICT access and usage in households and individuals (with a greater number of regions around the average) than in the values of technological readiness. In fact, the results of spatial autocorrelation demonstrate that, at the present time, the availability of broadband is not a variable that responds to regional differences in the capacity to access and use internet for advanced purposes. On the contrary, greater variability was detected among regions within a single country with regard to the ICT access and usage by households and individuals sub-pillar. On the basis of this information, it is concluded that European regions converge in ICT access and usage by households and individuals, while the inequalities continue to be greater for ICT access and usage by enterprises and the capacity to adopt-absorb technology. This may be partly explained by the use of data of national origin that is subsequently weighted and extrapolated for the analysis at regional level of ICT access and usage by enterprises. These conclusions highlight the need to reflect on the possible interest in using, for future editions of the $\mathrm{RCl}$, other variables with data of regional origin and which refer to advanced uses of ICTs that adjust to the current approach to digital inequality at regional level in Europe.

Consequently, spatial autocorrelation analysis is an appropriate technique for analysing the digital inequalities at territorial level in Europe and territorial diffusion of ICT as it helps to identify the influence between neighbouring regions in this process. In a European model of centreperiphery digital development, knowledge of how geographical proximity affects ICT access and usage may help establish measures to reduce digital inequalities between regions. This could be achieved through the design and implementation of ICT policies that are not only in accordance 
with the socio-economic characteristics of the region, but also with the capacity for diffusion between neighbouring regions.

Thus, in this study, with the application of spatial autocorrelation analysis to the variables of ICT access and usage, greater knowledge of digital development at regional level in Europe has been obtained. This is a relevant scientific contribution in that it paves the way to proposing the inclusion of other regionalised variables on ICT usage by individuals in European regions in the TR pillar. This could help to identify inequalities in digital development at regional level in Europe in a more appropriate and up-to-date way. These contributions would make it possible for analyses based on the $\mathrm{RCI}$ to not only become ideal scientific tools, but also to constitute a step forward in enabling the development of suitable and coherent regional policies that are consistent with national and regional competitiveness strategies (Szeles, 2018; Otioma et al., 2019). All to be undertaken in keeping with other policies designed to increase and improve the digital skills of regions that are lagging behind (Boli \& Botrić, 2018), taking into account the spatiality of this phenomenon (Soja, 2009). In this way, the value of the spatial component for technological readiness is enhanced, as a geographical opportunity (proximity) that may help to increase or reduce pre-existing spatial inequalities between neighbouring regions, regardless of whether unequal ICT access and usage is conditioned by other geographical factors (infrastructures, equipment, population density, etc.) or stems from social, economic, institutional, political or structural factors.

However, this research also has a number of limitations. On the one hand, the data of variables at regional level corresponding to ICT access and usage by enterprises and technology adoptionabsorption are not available. On the other hand, the regional statistics on ICT access and usage for Europe are very limited. In order to carry out further in-depth spatial studies on the technological readiness of European regions (both for households and individuals and for enterprises) and its influence on regional competitiveness through the application of spatial autocorrelation analysis, the incorporation of a greater number of regional variables is needed. In this type of studies, it should be taken into account that extrapolating data from a higher order spatial unit (national level) to lower order spatial units (regional level) spatially contiguous, leading to higher spatial autocorrelation (spatial clusters), which would lead to a misinterpretation of how geographical proximity affects (dis)equalities between regions.

The analysis of the influence of the spatial proximity of, and dependence between, neighbouring regions along with the regional socio-economic context, will be possible by means of applying 
other techniques such as multivariate spatial regression. This future line of research could help to explain regional imbalances in technological readiness and their role in regional competitiveness from a spatial perspective.

Acknowledgements: This paper derives directly from the scientific activity developed in the project PID2019-107993GB-100/ AEI / 10.13039/501100011033, funded by the Plan Estatal 2017-20 de Generación de Conocimiento- Proyectos I+D+i del Ministerio de Ciencia, Innovación y Universidades (Spain).

Authorship statement: The authors declare that there is no conflict of interest in relation to the publication of this article. The participation of the authors in the article is as follows. Reyes González-Relaño: come up with the idea and design of the research, literature review, data collection, selection of variables for the database, design of the methodology, interpretation and discussion of results as well as conclusions, development and writing, structure and content, supervision of editing, writing and cohesion of the original manuscript and revision of the final paper. Ángel Luis Lucendo-Monedero: data collection, design and construction of the database, design and development of the methodology (statistical analysis, tables, figures and GIS-mapping), interpretation and writing of results, supervision of structure, writing and content of the original manuscript and, revision of the final paper. Francisca Ruiz-Rodríguez: come up with the idea and design of the research, literature review, data collection, selection of variables for the database, design of the methodology, interpretation and discussion of results as well as conclusions, development and writing, structure and content, supervision of editing, writing and cohesion of the original manuscript and revision of the final paper. 


\section{References}

Aiginger K., \& Firgo M. (2017). Regional competitiveness: connecting an old concept with new goals. In R. Huggins \& P. Thompson (Eds.), Handbook of regions and competitiveness, contemporary theories and perspectives on economic development (pp. 155-191). Cheltenham and Massachusetts: Edward Elgar Publishing Limited. https://doi.org/10.4337/9781783475018

Aboelmaged, M. G. (2014). Predicting e-readiness at firm-level: An analysis of technological, organizational and environmental (TOE) effects on e-maintenance readiness in manufacturing firms. International Journal of Information Management, 34(5), 639651. https://doi.org/10.1016/j.ijinfomgt.2014.05.002

Annoni, P., \& Dijkstra, L. (2010). EU Regional Competitiveness Index: RCl 2010. Luxembourg: Publications Office of of the European Union. Retrieved from https://ec.europa.eu/regional_policy/sources/docgener/studies/pdf/6th_report/rci_20 13_report_final.pdf

Annoni, P., \& Dijkstra, L. (2019). EU Regional Competitiveness Index: RCI 2019. Luxembourg: Publications Office of the European Union. European Union. Retrieved from https://ec.europa.eu/regional_policy/sources/docgener/work/2019_03_rci2019.pdf

Añón Higón, D. (2012). The impact of ICT on innovation activities: Evidence for UK SMEs. International Small Business Journal, 30(6), 684699. https://doi.org/10.1177/0266242610374484

Aria, M., Gaeta, G. L., \& Marani, U. (2019). Similarities and differences in competitiveness among European NUTS2 regions: an empirical analysis based on 2010-2013 data. Social Indicators Research, 142(1), 431-450. hittps://doi.org/10.1007/s11205-018-1909-0

Avgerou, C. (2010). Discourses on ICT and development. Information Technologies \& International Development, 6(3), 1-18. Retrieved from http://eprints.Ise.ac.uk/35564/1/Discourses_on_ICT_and_development_\%28LSERO\%29. pdf

Bahrini, R., \& Qaffas, A. (2019). Impact of Information and Communication Technology on Economic Growth: Evidence from Developing Countries. Economies, 7(1), 21. https://doi.org/10.3390/economies7010021

Banerjee, A., Rappoport, P. N., \& Alleman, J. (2020). A Cross-Country Analysis of ICT Diffusion, Economic Growth, and Global Competitiveness. In J. Alleman, P. Rappoport, M. Hamoudia 
(Eds.), Applied Economics in the Digital Era. Palgrave Macmillan, Cham. https://doi.org/10.1007/978-3-030-40601-1_3

Biagi, F., \& Falk, M. (2017). The impact of ICT and e-commerce on employment in Europe. Journal of Policy Modeling, 39(1), 1-

18. https://doi.org/10.1016/j.jpolmod.2016.12.004

Billon, M., Ezcurra, R., \& Lera-López, F. (2009). Spatial effects in website adoption by firms in European regions. Growth and change, 40(1), 54-84. https://doi.org/10.1111/j.14682257.2008.00461.x

Billon, M., Lera-Lopez, F., \& Marco, R. (2017). Patterns of combined ICT use and innovation in the European regions. Journal of Global Information Technology Management, 20(1), 2842. https://doi.org/10.1080/1097198X.2017.1280302

Bisk, T., \& Bołtuć, P. (2017). Sustainability as growth. In L. Zacher (Eds.), Technology, Society and Sustainability (pp. 239-250). Springer, Cham. https://doi.org/10.1007/978-3-319-47164$\underline{8 \_16}$

Blut, M., \& Wang, C. (2020). Technology readiness: a meta-analysis of conceptualizations of the construct and its impact on technology usage. Journal of the Academy of Marketing Science, 48(4), 649-669. https://doi.org/10.1007/s11747-019-00680-8

Briglauer, W., Dürr, N. S., \& Gugler, K. (2019). A retrospective study on the regional benefits and spillover effects of high speed broadband networks: Evidence from German counties. Mannheim: ZEW-Centre for European Economic Research (Discussion Paper No. 19026). http://dx.doi.org/10.2139/ssrn.3423864

Bruno, G., Esposito, E., Genovese, A., \& Gwebu, K. L. (2011). A critical analysis of current indexes for digital divide measurement. The Information Society, 27(1), 1628. https://doi.org/10.1080/01972243.2010.534364

Buzai, G. D., \& Baxendale, C. A. (2009). Análisis exploratorio de datos espaciales. Geografía y $\begin{array}{lllll}\text { Sistemas de } \quad \text { Información } & \text { Geográfica, } & \text { Retrieved }\end{array}$ from https://ri.unlu.edu.ar/xmlui/bitstream/handle/rediunlu/702/Buzai_An\%c3\%a1lisis\%20Ex ploratorio\%20de\%20Datos\%20Espaciales. pdf? sequence=1\&isAllowed=y

Cairncross, F. (2018). The Death of distance-has distance died? RSAI Newsletter. New Series, 17, 8-9. Retrieved from https://www.regionalscience.org/images/PDF/RSAI\%20Newsletter November_2018.pdf 
Camagni, R. (2002). On the concept of territorial competitiveness: sound or misleading? Urban studies, 39(13), 2395-2411. https://doi.org/10.1080/0042098022000027022

Camagni, R., \& Capello, R. (2005). ICTS and territorial competitiveness in the era of internet. The Annals of Regional Science, 39, 421-438. https://doi.org/10.1007/s00168-005-0244-y

Castellacci, F., Consoli, D., \& Santoalha, A. (2020). The role of e-skills in technological diversification in European regions. Regional Studies, 54(8),

1123-

1135. https://doi.org/10.1080/00343404.2019.1681585

Cava-Ferreruela, I., \& Alabau-Munoz, A. (2006). Broadband policy assessment: A cross-national empirical analysis. Telecommunications Policy, 30(8-9), 445463. https://doi.org/10.1016/j.telpol.2005.12.002

Chasco, C. (2009). Análisis exploratorio de datos espaciales al servicio del Geomarketing. III Seminario sobre Nuevas Tecnologías de la Investigación, en el Marketing y la Comunicación. eParticipación. Retrieved from https://docplayer.es/9477800-Analisis-exploratorio-de-datosespaciales-al-servicio-del-geomarketing-1.html

Contreras-Cabrera, G. (2012). Asociacionismo en red para la integración sociodigital en

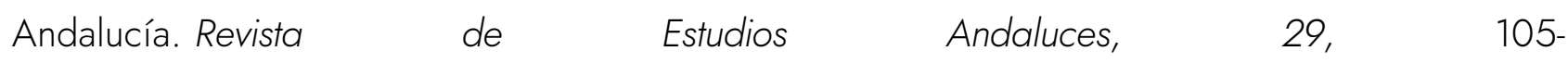
126. https://doi.org/10.12795/rea.2012.i29.05

Corrocher, N., \& Ordanini, A. (2002). Measuring the digital divide: a framework for the analysis of cross-country differences. Journal of Information technology, 17(1), 919. https://doi.org/10.1080/02683960210132061

Cruz-Jesus, F., Oliveira, T., \& Bacao, F. (2012). Digital divide across the European Union. Information \& Management, 49(6), 278-291. https://doi.org/10.1016/j.im.2012.09.003 D’Urso, P., De Giovanni, L., Massari, R., \& Sica, F. G. (2019). Cross Sectional and Longitudinal Fuzzy Clustering of the NUTS and Positioning of the Italian Regions with Respect to the Regional Competitiveness Index (RCl) Indicators with Contiguity Constraints. Social Indicators Research, 146(3), 609-650. https://doi.org/10.1007/s11205-019-02134-8

ESRI (2020). Analyzing Patterns toolset. Retrieved from

https://desktop.arcgis.com/es/arcmap/10.3/tools/spatial-statistics-toolbox/modeling-spatialrelationships.htm\#GUID-DDDFA1EE-4ED2-4126-9BB0-3E57E01D7885

European Commission (2010). A digital agenda for Europe. Retrieved from https://eurlex.europa.eu/legal-content/EN/TXT/HTML/?uri=CELEX:52015DC0192\&from=EN 
European Commission (2015). A Digital Single Market Strategy for Europe. Retrieved from https://eur-lex.europa.eu/legal-content/EN/TXT/?uri=celex\%3A52015DC0192

European Commission (2020). Digital Economy and Society Index- DESI. Retrieved from https://ec.europa.eu/digital-single-market/en/digital-economy-and-society-index-desi

Eurostat (2020). Data. Main Tables. Retrieved from https://ec.europa.eu/eurostat/web/regions/data/main-tables

Falch, M., \& Henten, A. (2018). Dimensions of broadband policies and developments. Telecommunications Policy, 42(9), 715-725.

https://doi.org/10.1016/j.telpol.2017.11.004

Grubesic, T. H., \& Murray, A. T. (2005). Geographies of imperfection in telecommunication analysis. Telecommunications Policy, 29(1), 69-94.

https://doi.org/10.1016/j.telpol.2004.08.001

Haefner, L., \& Sternberg, R. (2020). Spatial implications of digitization: State of the field and research agenda. Geography Compass, 14, e12544. https://doi.org/10.1111/gec3.12544

Hargittai, E. (2010). Digital na ( $t$ ) ives? Variation in internet skills and uses among members of the "net generation". Sociological inquiry, 80(1), 92-113. https://doi.org/10.1111/j.1475682X.2009.00317.x

Hunady, J., Pisar, P., \& Durcekova, I. (2020). R\&D Investments in the European ICT Sector: Implications for Business Performance. Business Systems Research: International journal of the Society for Advancing Innovation and Research in Economy, 11(3), 3044. https://doi.org/10.2478/bsrj-2020-0025

lammarino, S., Rodríguez-Pose, A., \& Storper, M. (2019). Regional inequality in Europe: evidence, theory and policy implications. Journal of economic geography, 19(2), 273298. https://doi.org/10.1093/jeg/lby021

Inklaar, R., O'Mahony, M., \& Timmer, M. (2005). ICT and Europe's productivity performance: industry-level growth account comparisons with the United States. Review of Income and Wealth, 51(4), 505-536. https://doi.org/10.1111/j.1475-4991.2005.00166.x

International Telecommunication Union (2018). Measuring the Information Society Report 2018. Geneva: ITU. Retrieved from https://www.itu.int/en/ITUD/Statistics/Documents/publications/misr2018/MISR-2018-Vol-1-E.pdf 
Jeong, N., Yoo, Y., \& Heo, T. Y. (2009). Moderating effect of personal innovativeness on mobile-RFID services: Based on Warshaw's purchase intention model. Technological Forecasting and Social Change, 76(1), 154-164. https://doi.org/10.1016/j.techfore.2008.08.007

Jordá -Borrell, R., \& López-Otero, J. (2020). Economic growth factors in developing countries: the role of ICT. Boletín de la Asociación de Geógrafos Españoles, (86). https://doi.org/10.21138/bage.2979

Jordá-Borrell, R., Ruiz-Rodríguez, F., \& González-Relaño, R. (2015). Factors and taxonomy of technology purchase (TP) by internationalized innovative companies in peripheral European regions. Papers in Regional Science, 94, S139-S174. https://doi.org/10.1111/pirs. 12172

Keating, M. (2017). Contesting European regions. Regional Studies, 51(1), 918. https://doi.org/10.1080/00343404.2016.1227777

Koutroumpis, P. (2009). The economic impact of broadband on growth: A simultaneous approach. Telecommunications policy, 33(9), 471-485.

https://doi.org/10.1016/j.telpol.2009.07.004

Lobo, B., Alam, M., \& Whitacre, B. (2020). Broadband speed and unemployment rates: Data and measurement issues. Telecommunications Policy, 44(1), 101829.

https://doi.org/10.1016/j.telpol.2019.101829

López Hernández, F.A., y Palacios Sánchez, M.A. (2000). Distintos modelos de dependencia espacial. Análisis de autocorrelación. In ASEPELT-España, Reunión Anual (Actas de la XIV Reunión). Oviedo: ASEPELT. Retrieved from

https://repositorio.upct.es/bitstream/handle/10317/1513/dmd.pdf?sequence=1\&isAllowed=y

Lucendo-Monedero, A. L., Ruiz-Rodríguez, F., \& González-Relaño, R. (2019). Measuring the digital divide at regional level. A spatial analysis of the inequalities in digital development of households and individuals in Europe. Telematics and Informatics, 41, 197217. https://doi.org/10.1016/j. tele.2019.05.002

Malecki, E. (2004). Jockeying for position: what it means and why it matters to regional development policy when places compete. Regional studies, 38(9), 1101 1120. https://doi.org/10.1080/0034340042000292665

Malecki, E. J. (2007). Cities and regions competing in the global economy: knowledge and local development policies. Environment and Planning C: Government and policy, 25(5), 638654. https://doi.org/10.1068/c0645 
Möbius, P., \& Althammer, W. (2020). Sustainable competitiveness: a spatial econometric analysis of European regions. Journal of Environmental Planning and Management, 63(3), 453480. https://doi.org/10.1080/09640568.2019.1593005

Moroz, M. (2017). The level of development of the digital economy in Poland and selected European countries: a comparative analysis. Foundations of management, 9(1), 175 190. https://doi.org/10.1515/fman-2017-0014

Novo-Corti, I., \& Barreiro-Gen, M. (2015). Public policies based on social networks for the introduction of technology at home: Demographic and socioeconomic profiles of households. Computers in Human Behavior, 51, 1216-1228. https://doi.org/10.1016/j.chb.2014.12.040

OECD-Organization for Economic Cooperation and Development (2008). Handbook on Constructing Composite Indicators: Methodology and User Guide. Paris: JRC European Commission, OECD. Retrieved from https://www.oecd.org/std/42495745.pdf

Otioma, C., Madureira, A. M., \& Martinez, J. (2019). Spatial analysis of urban digital divide in Kigali, Rwanda. GeoJournal, 84(3), 719-741. https://doi.org/10.1007/s10708-018-9882-3

Parasuraman, A. (2000). Technology Readiness Index (TRI) a multiple-item scale to measure readiness to embrace new technologies. Journal of service research, 2(4), 307 320. https://doi.org/10.1177/109467050024001

Parasuraman, A., \& Colby, C. L. (2015). An updated and streamlined technology readiness index: TRI 2.0. Journal of service research, 18(1), 59-

74. https://doi.org/10.1177/1094670514539730

Peña-Vinces, J. C., Cepeda-Carrión, G., \& Chin, W. W. (2012). Effect of ITC on the international competitiveness of firms. Management decision, 50(6), 1045-1061.

https://doi.org/10.1108/00251741211238328

Perez-Castro, M. Á., Mohamed-Maslouhi, M., \& Montero-Alonso, M. Á (2021): The digital divide and its impact on the development of Mediterranean countries. Technology in Society, 64, 101452. https://doi.org/10.1016/j.techsoc.2020.101452

Pick, J. B., \& Nishida, T. (2015). Digital divides in the world and its regions: A spatial and multivariate analysis of technological utilization. Technological Forecasting and Social Change, 91, 1-17. https://doi.org/10.1016/j.techfore.2013.12.026 
Portulans Institute (2019). Network Readiness Index 2019. Washington D.C., USA. Retrieved from https://networkreadinessindex.org/2019/wp-content/uploads/2020/03/The-NetworkReadiness-Index-2019-New-version-March-2020-2.pdf

Ragnedda, M., \& Muschert, G. W. (Eds.). (2017). Theorizing digital divides. London: Routledge. https://doi.org/10.4324/9781315606002

Ragnedda, M., \& Kreitem, H. (2018). The three levels of digital divide in East EU countries. World of Media. Journal of Russian Media and Journalism Studies, 1(4), 5 26. https://doi.org/10.30547/worldofmedia.4.2018.1

Ramírez-Correa, P., Grandón, E. E., \& Rondán-Cataluña, F. J. (2020). Users segmentation based on the Technological Readiness Adoption Index in emerging countries: The case of Chile. Technological Forecasting Social Change, 155, 120035. https://doi.org/10.1016/j.techfore.2020.120035

Richardson, L., \& Bissell, D. (2019). Geographies of digital skill. Geoforum, 99, 278286. https://doi.org/10.1016/j.geoforum.2017.09.014

Rivera, N., \& Galicia, L. (2016). La escala geográfica como concepto integrador en la comprensión de problemas socio-ambientales. Investigaciones Geográficas, Boletín del Instituto de Geografía, (89), 137-153. https://doi.org/10.14350/rig.47515

Rohman, I., \& Bohlin, E. (2014). Decomposition analysis of the telecommunications sector in Indonesia: What does the cellular era shed light on? Telecommunications Policy, 38(3), 248263. https://doi.org/10.1016/j.telpol.2013.10.006

Ruiz-Rodríguez, F., González-Relaño, R., \& Lucendo-Monedero, A.L. (2020). Comportamiento espacial del uso de las TIC en los hogares e individuos. Un análisis regional europeo. Investigaciones Geográficas, (73), 57-74. https://doi.org/10.14198/INGEO2020.RRGRLM

Ruiz-Rodríguez, F., Lucendo-Monedero, A. L., \& González-Relaño, R. (2018). Measurement and characterisation of the Digital Divide of Spanish regions at enterprise level. A comparative analysis with the European context. Telecommunications Policy, 42(3), 187211. https://doi.org/10.1016/j. telpol.2017.11.007

Sáiz Peña, J. (2019). La Sociedad Digital en España 2018. Madrid: Fundación Telefónica.

Sánchez-Moral, S. (2015). Territorio, transformación productiva, equidad y redes. Revista de Estudios Andaluces, 32, 49-75. http://dx.doi.org/10.12795/rea.2015.i32.03 
Saprikis, V., Markos, A., Zarmpou, T., \& Vlachopoulou, M. (2018). Mobile shopping consumers' behavior: An exploratory study and review. Journal of theoretical and applied electronic commerce research, 13(1), 71-90. https://doi.org/10.4067/S0718$\underline{18762018000100105}$

Scheerder, A., van Deursen, A., \& van Dijk, J. (2017). Determinants of internet skills uses and outcomes. A systematic review of the second-and third-level digital divide. Telematics and informatics, 34(8), 1607-1624. https://doi.org/10.1016/j.tele.2017.07.007

Schlichter, B. R., \& Danylchenko, L. (2014). Measuring ICT usage quality for information society building. Government Information Quarterly, 37(1), 184. https://doi.org/10.1016/j.giq.2013.09.003

Schmidthuber, L., Maresch, D., \& Ginner, M. (2020). Disruptive technologies and abundance in the service sector-toward a refined technology acceptance model. Technological Forecasting and Social Change, 155, 119328. https://doi.org/10.1016/j.techfore.2018.06.017

Serrano, R. M., \& Vayá, E. V. (2002). Econometría espacial: nuevas técnicas para el análisis regional. Una aplicación a las regiones europeas. Investigaciones Regionales-Journal of Regional Research, (1), 83-106. Retrieved from https://www.redalyc.org/pdf/289/28900104.pdf

Sbeppard, E. (2003). Competition in Space and between Places. In E. Sheppard \& T. J. Barnes (Eds.), A Companion to Economic Geography (pp. 169-186). Oxford: Blackwell Publishing Ltd. https://doi.org/10.1002/9780470693445.ch11

Snieška, V., \& Bruneckienè, J. (2009). Measurement of Lithuanian regions by regional competitiveness index. Engineering economics, 61(1). Retrieved from https://etalpykla.lituanistikadb.lt/object/LT-LDB-

0001:|.04 2009 1367168617711/J.04 2009 1367168617711.pdf

Soja, E. W. (2009). Taking space personally. In B. Warf and S. Arias (Eds.), The spatial turn: Interdisciplinary perspectives (pp. 11-35). London and New York: Routledge.

Szeles, M. R. (2018). New insights from a multilevel approach to the regional digital divide in the European Union. Telecommunications Policy, 42(6), 452-463.

https://doi.org/10.1016/j.telpol.2018.03.007

Tobler, W. (2004). On the first law of geography: A reply. Annals of the Association of American Geographers, 94(2), 304-310.

https://doi.org/10.1111/j.1467-8306.2004.09402009.x 
Tranos, E., \& Gillespie, A. (2009). The spatial distribution of Internet backbone networks in Europe: a metropolitan knowledge economy perspective. European urban and regional studies, 16(4), 423-437. https://doi.org/10.1177/0969776409340866

Tranos, E. (2012). The causal effect of the internet infrastructure on the economic development of European city regions. Spatial Economic Analysis, 7(3), 319337. https://doi.org/10.1080/17421772.2012.694140

Tsetsi, E., \& Rains, S. A. (2017). Smartphone Internet access and use: Extending the digital divide and usage gap. Mobile Media \& Communication, 5(3), 239255. https://doi.org/10.1177/2050157917708329

Uljas, S. (2019). The European digital single market strategy: Local indicators of spatial association 2011-2016. Telecommunications Policy, 43(5), 393-410.

https://doi.org/10.1016/j.telpol.2018.10.003

United Nations Development Programme (2017). Human Development for Everyone (Vol. 2016). New York: UNDP. Retrieved from

http://hdr.undp.org/sites/default/files/2016_human_development_report.pdf

Van Deursen, A. J., \& Van Dijk, J. A. (2019). The first-level digital divide shifts from inequalities in physical access to inequalities in material access. New media \& society, 21(2), 354375. https://doi.org/10.1177/1461444818797082

Van Dijk, J. A. (2006). Digital divide research, achievements and shortcomings. Poetics, 34(4-5), 221-235. https://doi.org/10.1016/j.poetic.2006.05.004

Vicente, M. R., \& López, A. J. (2011). Assessing the regional digital divide across the European Union-27. Telecommunications Policy, 35(3), 220237. https://doi.org/10.1016/j.telpol.2010.12.013

Vicente, M. R., García-Muñiz, A. S., \& Billon, M. (2020). The regional shaping of ICT: Exploring the links between ICT research, innovation and diffusion. In Society and Technology (pp. 66-78). Routledge.

World Economic Forum (2018). The Global Competitiveness Report 2018. Retrieved from http://www3.weforum.org/docs/GCR2018/05FullReport/TheGlobalCompetitivenessRep ort2018.pdf 
Yu, L. (2006). Understanding information inequality: Making sense of the literature of the information and digital divides. Journal of Librarianship and Information Science, 38(4), 229252. https://doi. org/10.1177/0961000606070600

Ziemba, E. (2019). The contribution of ICT adoption to the sustainable information society. Journal of Computer Information Systems, 59(2), 116-126.

https://doi.org/10.1080/08874417.2017.1312635 


\section{Annex 1. The Technological Readiness (TR) Pillar of the Regional Competitiveness Index (RCl)}

The Technological Readiness (TR) pillar aims to measure the level at which households and firms use and adopt existing technologies, since the access to and use of technological infrastructures are a key element for the development of countries and regions. The $\mathrm{RCl}$ considers that ICTs have changed the organisational structure of enterprises facilitating the adoption of new technologies, increasing productivity and streamlining business processes, making the use of ICTs is a very important element of competitiveness. Moreover, ICTs have also changed people's daily lives, what conditions the way in which companies' employees can efficiently use new technologies. Thus, Technological Readiness (TR) measures technological readiness by focusing also on the use of ICT by households as an indicator of the level of implementation of technologies in the population (Annoni \& Dijkstra, 2010).

This pillar is composed by 2 sub-pillars (Figure A. 1): Technological Readiness-Households (TR-HI) and Enterprises (TR-E), which, in turn, are formed by different indicators describing the access and use of technology by individuals/households and enterprises respectively. The sub-pillar related to personal use (households) has 3 indicators collected at NUTS2 level, while the subpillar related to technology readiness of enterprises is described by 6 indicators at country level (Table A.1). The overall technology readiness sub-pillar score is calculated as the simple arithmetic mean of the two sub-pillar scores. Since for the firm sub-pillar the sub-scores are only available at the country level only, these values have been assigned equally to all regions of that country (Annoni \& Dijkstra, 2010).

The imputation of regional data when only national data are available is done by the procedure of distributing the national values of the indicator to be estimated $(Y)$ for the regions according to the average performance of that region with respect to the country. The average performance is calculated as an average ratio of the national and regional values of all indicators, observed at the regional level, that show a significant correlation with the indicator to be estimated $(Y)$, and are therefore considered as 'benchmark indicators' for the indicator to be estimated (Y) (Annoni \& Dijkstra, 2010). 
Figure A.1. Pillar Technological Readiness of RCI 2019

\section{PILLAR TECHNOLOGICAL READINESS}

\section{Sub-pillar \\ Households (TR-HI)}

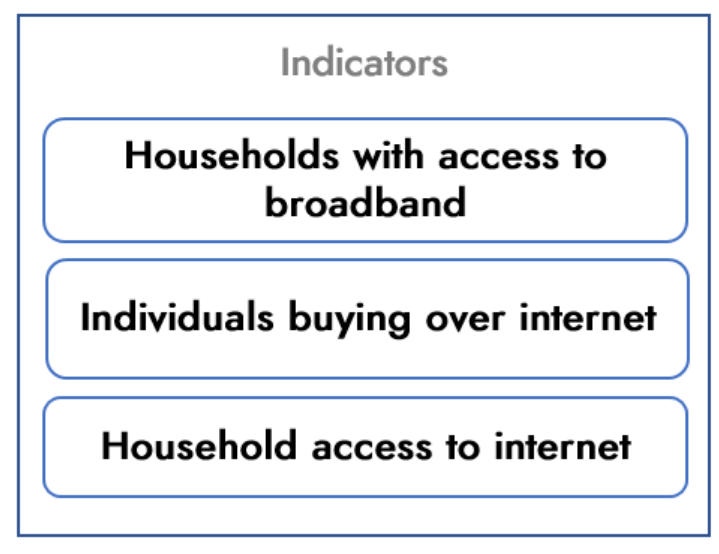

\section{Sub-pillar \\ Enterprises (TR-E)}

\section{Indicators}

- Availability of latest technologies

- Firm-level technology absorption

- FDI and technology transfer

- Enterprises having purchased online (at least 1\%)

- Enterprises having received orders online (at least $1 \%$ )

- Enterprises with fixed broadband access

Source: own elaboration based on Annoni \& Dijkstra (2010) 
Table A.1. Description of the Indicators of the Pillar Technological Readiness of RCI 2019

\begin{tabular}{|c|c|c|c|c|c|}
\hline Pillar name & Indicators & Source & $\begin{array}{c}\text { Geographical } \\
\text { level }\end{array}$ & Measurement & $\begin{array}{c}\text { Reference } \\
\text { year }\end{array}$ \\
\hline $\begin{array}{l}\text { Technological } \\
\text { readiness regional }\end{array}$ & $\begin{array}{l}\text { Households with } \\
\text { access to } \\
\text { broadband }\end{array}$ & $\begin{array}{c}\text { Eurostat Regional } \\
\text { Information Statistics: } \\
\text { isoc_r_broad_h }\end{array}$ & NUTS2 & $\begin{array}{l}\% \text { of total } \\
\text { households }\end{array}$ & 2018 \\
\hline $\begin{array}{l}\text { Technological } \\
\text { readiness regional }\end{array}$ & $\begin{array}{l}\text { Individuals buying } \\
\text { over internet }\end{array}$ & $\begin{array}{c}\text { Eurostat Regional } \\
\text { Information Statistics: } \\
\text { isoc_r_blt12_i }\end{array}$ & NUTS2 & $\%$ of individuals & 2018 \\
\hline $\begin{array}{l}\text { Technological } \\
\text { readiness regional }\end{array}$ & $\begin{array}{l}\text { Household access } \\
\text { to internet }\end{array}$ & $\begin{array}{c}\text { Eurostat Regional } \\
\text { Information Statistics: } \\
\text { isoc_r_iacc_h }\end{array}$ & NUTS2 & $\begin{array}{l}\% \text { of total } \\
\text { households }\end{array}$ & 2018 \\
\hline $\begin{array}{l}\text { Technological } \\
\text { readiness national }\end{array}$ & $\begin{array}{c}\text { Availability of latest } \\
\text { technologies }\end{array}$ & $\begin{array}{l}\text { World Economic } \\
\text { Forum Global } \\
\text { Competitiveness } \\
\text { Index }\end{array}$ & country & 1-7 (best) & 2017 \\
\hline $\begin{array}{l}\text { Technological } \\
\text { readiness national }\end{array}$ & $\begin{array}{l}\text { Firm-level } \\
\text { technology } \\
\text { absorption }\end{array}$ & $\begin{array}{l}\text { World Economic } \\
\text { Forum Global } \\
\text { Competitiveness } \\
\text { Index }\end{array}$ & country & 1-7 (best) & 2017 \\
\hline $\begin{array}{l}\text { Technological } \\
\text { readiness national }\end{array}$ & $\begin{array}{c}\text { FDI and technology } \\
\text { transfer }\end{array}$ & $\begin{array}{l}\text { World Economic } \\
\text { Forum Global } \\
\text { Competitiveness } \\
\text { Index }\end{array}$ & country & 1-7 (best) & 2017 \\
\hline $\begin{array}{l}\text { Technological } \\
\text { readiness national }\end{array}$ & $\begin{array}{l}\text { Enterprises having } \\
\text { purchased online } \\
\text { (at least 1\%) }\end{array}$ & $\begin{array}{c}\text { Eurostat Community } \\
\text { Survey on ICT usage } \\
\text { and e-commerce: } \\
\text { tin00112 }\end{array}$ & country & $\begin{array}{c}\text { \% of enterprises } \\
\text { with at least } 10 \\
\text { persons employed } \\
\text { in the given NACE } \\
\text { sectors, by size } \\
\text { class. NACE Rev } 2 \\
\text { since } 2009\end{array}$ & $\begin{array}{c}\text { average } \\
2016-2018\end{array}$ \\
\hline $\begin{array}{l}\text { Technological } \\
\text { readiness national }\end{array}$ & $\begin{array}{l}\text { Enterprises having } \\
\text { received orders } \\
\text { online (at least 1\%) }\end{array}$ & $\begin{array}{c}\text { Eurostat Community } \\
\text { Survey on ICT usage } \\
\text { and e-commerce: } \\
\text { tin00111 }\end{array}$ & country & $\begin{array}{c}\% \text { of enterprises } \\
\text { with at least } 10 \\
\text { persons employed } \\
\text { in the given NACE } \\
\text { sectors, by size } \\
\text { class. NACE Rev } 2 \\
\text { since } 2009\end{array}$ & $\begin{array}{c}\text { average } \\
2016-2018\end{array}$ \\
\hline $\begin{array}{l}\text { Technological } \\
\text { readiness national }\end{array}$ & $\begin{array}{c}\text { Enterprises with } \\
\text { fixed broadband } \\
\text { access }\end{array}$ & $\begin{array}{c}\text { Eurostat Community } \\
\text { Survey on ICT usage } \\
\text { and e-commerce: } \\
\text { tin00090 }\end{array}$ & country & $\begin{array}{l}\% \text { of enterprises } \\
\text { with at least } 10 \\
\text { persons employed } \\
\text { in the given NACE } \\
\text { sectors. NACE Rev } \\
2 \text { since } 2009\end{array}$ & $\begin{array}{c}\text { average } \\
2015-2016\end{array}$ \\
\hline
\end{tabular}

Source: Annoni \& Dijkstra (2019) 